\title{
3-Arylisoxazolyl-5-Carboxylic Acid and 5-(Hydroxymethyl)-3-Aryl-2-Isoxazoline as Molecular Platforms for Liquid-Crystalline Materials
}

\author{
Aline Tavares, ${ }^{a}$ Paolo R. Livotto, ${ }^{a}$ Paulo F. B. Gonçalves ${ }^{b}$ and Aloir A. Merlo ${ }^{*, a}$ \\ ${ }^{a}$ Instituto de Química, Universidade Federal do Rio Grande do Sul, 91501-970 Porto Alegre-RS, Brazil \\ ${ }^{b}$ Centro Universitário La Salle, 92010-000 Canoas-RS, Brazil
}

\begin{abstract}
A síntese de uma plataforma molecular para materiais líquido-cristalinos derivados do ácido 3-arilisoxazolil-5-carboxílico (1) e do 5-(hidroximetil)-3-aril-2-isoxazolina (2) é descrita. Os intermediários 1 e 2 são obtidos através da reação de cicloadição [3+2] 1,3-dipolar entre arilóxidos de nitrilas e os dipolarófilos ácido acrílico e álcool alílico, respectivamente. Os compostos cristais líquidos são sintetizados através de uma estratégia de alongamento molecular do núcleo primitivo isoxazolínico pela conexão de subunidades arilacetilênicas, as quais foram obtidas da reação de Sonogashira. Sob essas condições, séries de cristais líquidos 5a-c, 6, 7a-g e 8a-d têm sido sintetizadas com rendimentos de médios para bons. Os compostos finais apresentam propriedades líquido-cristalinas nematogênica e esmectogênica. Um cálculo DFT no nível B3LYP/6-31G(d,p) é também apresentado e alguns parâmetros estruturais obtidos são analisados.
\end{abstract}

The synthesis of the molecular platform for liquid-crystalline materials based on 3-arylisoxazolyl-5-carboxylic acid (1) and 5-(hydroxymethyl)-3-aryl-2-isoxazoline (2) is described. The key intermediates $\mathbf{1}$ and $\mathbf{2}$ are obtained by [3+2] 1,3-dipolar cycloaddition reaction between an arylnitrile oxide and an acrylic acid and allylic alcohol as the dipolarophile. The liquid crystals (LC) compounds are synthesized through a "molecular elongation strategy" from the initial isoxazolinic core by connecting the arylacetylene moiety obtained from the Sonogashira reaction. Under these conditions, the series of liquid crystals 5a-c, 6, 7a-g and 8a-d have been successfully synthesized in fair to good yields. The final compounds display nematic and smectic liquid-crystalline properties. The structural properties of the series of the liquid crystals has been studied using DFT methods at level B3LYP/6-31G(d,p). The equilibrium geometries in the gas phase are presented and analyzed.

Keywords: 3,5-disubstituted isoxazolines, [3+2] 1,3-dipolar cycloaddition, liquid crystals, molecular platform

\section{Introduction}

The [3+2] 1,3-dipolar cycloaddition reaction of a nitrile oxide to an alkene or alkyne has proven to be extremely useful in the preparation of a variety of compounds in organic chemistry. Among the various classes of compounds which are prepared from these cycloadducts are enones, ${ }^{1}$ 1,3-amino alcohols, ${ }^{2} \beta, \gamma$ dihydroxy ketones ${ }^{3}$ and $\beta$-hydroxy ketones. ${ }^{4}$ In the area of materials, the construction of the isoxazoline and isoxazole rings by this methodology constitute an easy way to prepare a molecular platform for the synthesis of smart molecules, such as polymers and non-polymer liquid-crystallines materials. ${ }^{5}$

*e-mail: aloir@iq.ufrgs.br
Our previous results showed that the introduction of an isoxazoline ring flanked by aromatic rings or polar groups opened a route to prepare useful intermediates in the field of liquid crystals. ${ }^{6}$ Herein we describe the preparation of four homologous series of 3,5-disubstituted isoxazoline rings. A complete study of the thermal behavior of these compounds is also presented with the goal to understanding the correlation between the molecular structure and liquid crystal parameters.

Based upon the considerations discussed above, we now report a convenient and practical route to the synthesis of isoxazoline ring platform for liquid crystal (LC) materials. The compounds from series $\mathbf{5}$ and $\mathbf{6}$ are derived from 3-arylisoxazolyl-5-carboxylic acid (1) while the members of the homologous series $\mathbf{7}$ and $\mathbf{8}$ are derived from 5-(hydroxymethyl)-3-aryl-2-isoxazoline (2). 


\section{Results and Discussion}

Synthesis

To synthesize the isoxazoline LC, the molecular platforms $\mathbf{1}$ and $\mathbf{2}$ bearing carboxyl or hydroxyl groups suitable for further derivation were prepared (Chart I). The acid 1a-d and alcohol 2a-d were obtained using [3+2] 1,3-dipolar cycloadditions according to reference 6.

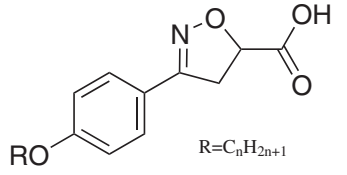

1a $\mathrm{n}=n$-heptyl; $\mathbf{1 b} \mathrm{n}=n$-octyl; $\mathbf{1 c} \mathrm{n}=n$-nonyl; $1 \mathbf{d} \mathrm{n}=n$-decyl.

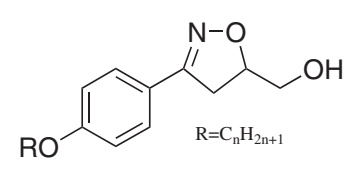

2a $\mathrm{n}=n$-heptyl; $\mathbf{2 b} \mathrm{n}=n$-octyl; 2c $\mathrm{n}=n$-nonyl; 2d $\mathrm{n}=n$-decyl.
Chart I. The isoxazoline platforms $\mathbf{1}$ and $\mathbf{2}$.

To achieve our goal of the isoxazoline LC material it was necessary to synthesize the phenols $\mathbf{3}$ and $\mathbf{4}$ as the chemical counterparts of the acid $\mathbf{1}$. The synthesis of the key intermediates $\mathbf{3}$ is reported elsewhere. ${ }^{6}$ Compound $\mathbf{4}$ was prepared following the experimental procedure to $\mathbf{3}$.

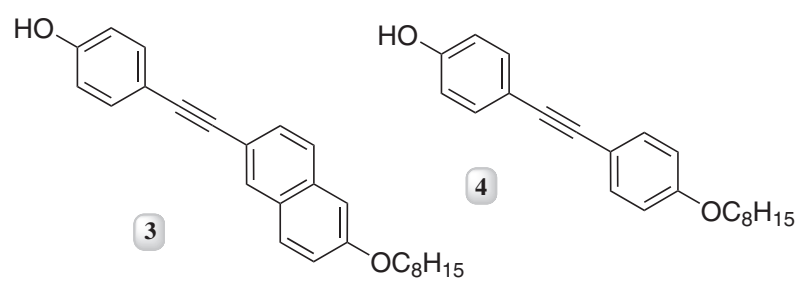

The chemical connection between the intermediates 3 and $\mathbf{4}$ and acid $\mathbf{1}$ was made through an esterification reaction using the DCC-DMAP protocol. Thus, the compounds 5a-c and $\mathbf{6}$ were synthesized as representative members of these homologous series.

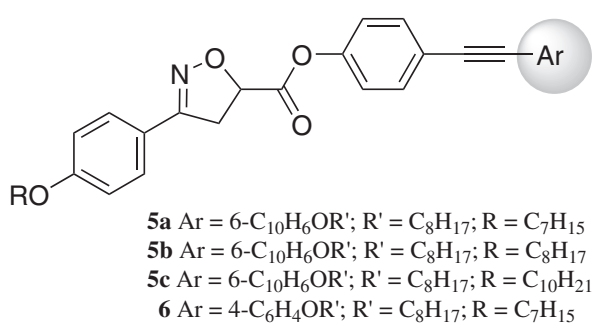

The third and fourth homologous series $7 \mathbf{a}-\mathbf{g}$ and $\mathbf{8 a - d}$ are derived from 5-(hydroxymethyl)-3-aryl-2-isoxazoline (2). The compounds 7a-g were quickly prepared by an esterification reaction (DCC/DMAP) between the corresponding $p$ - $n$-alkoxybenzoic $\operatorname{acid}^{7}$ and the alcohol 2. In order to synthesize the elongated (anisotropic) liquid- crystalline isoxazolines 8a-d, we again applied the DCC/ DMAP protocol to introduce the ester linkage by reaction of $p$-bromobenzoic acid with the alcohol 2a. To accomplish the synthesis of the homologous series $\mathbf{8 a - d}$ the triple bond was inserted through the Sonogashira cross-coupling reaction between the 1-alkoxy-4-ethynylbenzene ${ }^{8}$ and the ester derived from $p$-bromobenzoic acid.
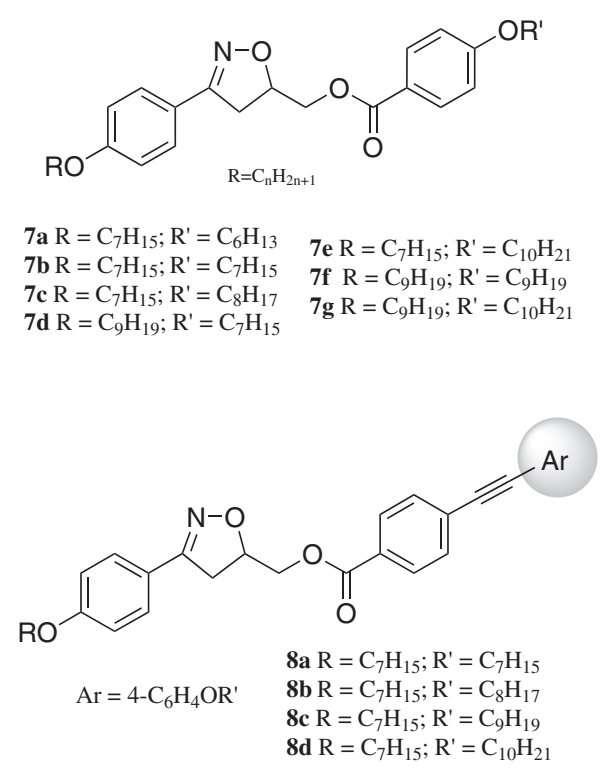

\section{Liquid-crystalline behavior}

Thermal analysis of all isoxazolines 5a-c, 6, 7a-g and 8a-d was performed by differential scanning calorimetry (DSC). The texture of the mesophase ${ }^{9}$ was identified by microscopy studies on cooling from the isotropic liquid state of the samples (Figure 1). The transition temperatures and enthalpy values were collected from a second heating scan and is compiled in Table 1. Polarizing optical photomicrographs of the representative LCs are shown in Figure 1. The 3-phenylisoxazolyl-5-carboxylate esters 5a-c exhibited enantiotropic liquid-crystalline properties (Figures 1a and 1b). The ester 6 did not exhibit mesomorphic behavior under optical polarized light microscopy (Figure 1c). The LC 5-(hydroxymethyl)3-aryl-2-isoxazolyl benzoates 7c-g and 8a-d displayed monotropic liquid-crystalline phase where the smectic $\mathrm{C}$ and nematic mesophases were observed in these series (Table 1), respectively.

The mesophase characterization was made by polarized optical microscopy studies (POM, Figure 1) and the enthalpy values were obtained from DSC traces (Figure 2). The schlieren textures of series 5a-c and 7d-g show singularity lines with two and four dark brushes, which correspond to the extinction orientation of the 
Table 1. Transition temperatures $\left({ }^{\circ} \mathrm{C}\right)$ for homologous series $\mathbf{5 a - c}, \mathbf{6}, \mathbf{7 a - g}$ and $\mathbf{8 a - d}$ and enthalpies values $\left(\Delta \mathrm{H}, \mathrm{kcal}\right.$ mol $\left.{ }^{-1}\right)$

\begin{tabular}{|c|c|c|c|c|c|c|}
\hline \multirow{2}{*}{ Entry } & \multirow{2}{*}{$\begin{array}{l}\mathrm{R} / \mathrm{R}^{\prime} \\
\mathrm{C}_{\mathrm{n}} \mathrm{H}_{2 \mathrm{n}+1}\end{array}$} & \multicolumn{2}{|c|}{ Phase Transition Temperatures $/\left({ }^{\circ} \mathrm{C}\right)$} & \multirow{2}{*}{$\Delta \mathrm{T}^{\mathrm{d}}$} & \multicolumn{2}{|c|}{ Enthalpies values } \\
\hline & & Heating & Cooling & & Melt $^{c}$ & Iso-phase- $\mathrm{K}^{\mathrm{d}}$ \\
\hline & & & & \multicolumn{3}{|c|}{$\begin{array}{l}5 \mathrm{Ar}=6-\mathrm{C}_{10} \mathrm{H}_{6} \mathrm{OR} ; \mathrm{R}^{\prime}=\mathrm{R}^{\prime}=\mathrm{C}_{\mathrm{n}} \mathrm{H}_{2 \mathrm{n}+1} \\
\mathbf{6} \mathrm{Ar}=4-\mathrm{C}_{6} \mathrm{H}_{4} \mathrm{OR} ; \mathrm{R}^{\prime}=\mathrm{R}^{\prime}=\mathrm{C}_{\mathrm{n}} \mathrm{H}_{2 \mathrm{n}+1}\end{array}$} \\
\hline $5 \mathrm{a}$ & $7 / 8$ & K $144.5^{\mathrm{a}} \mathrm{N} 148.0^{\mathrm{a}} \mathrm{I}$ & I $142.9 \mathrm{~N} 136.9 \mathrm{~K}$ & 3.5 & 6.74 & I $0.015 \mathrm{~N} 6.59 \mathrm{~K}$ \\
\hline $5 b$ & $8 / 8$ & $\mathrm{~K} 134.4^{\mathrm{a}} \mathrm{N} 150.5^{\mathrm{a}} \mathrm{I}$ & I $144.0 \mathrm{~N} 127.3 \mathrm{~K}$ & 16.1 & 6.05 & I $0.031 \mathrm{~N} 6.00 \mathrm{~K}$ \\
\hline $5 \mathrm{c}$ & $10 / 8$ & $\mathrm{~K} 142.6^{\mathrm{a}} \mathrm{N} 151.0^{\mathrm{a}} \mathrm{I}$ & I $149.5^{\mathrm{a}} \mathrm{N} 130.7 \mathrm{~K}$ & 8.4 & 5.93 & $\mathrm{I}^{\mathrm{f}} \mathrm{N} 6.01 \mathrm{~K}$ \\
\hline \multirow[t]{2}{*}{6} & $7 / 8$ & K 129.5 I & I $116.1 \mathrm{~K}$ & - & 12.31 & I $12.74 \mathrm{~K}$ \\
\hline & & & & \multicolumn{3}{|c|}{$\mathrm{R}=\mathrm{R}^{\prime}=\mathrm{C}_{\mathrm{n}} \mathrm{H}_{2 \mathrm{n}+1}$} \\
\hline $7 \mathrm{a}$ & $7 / 6$ & K 100.8 I & I $73.7 \mathrm{~K}$ & - & 13.07 & I $12.87 \mathrm{~K}$ \\
\hline $7 b$ & $7 / 7$ & K 97.8 I & I $73.7 \mathrm{~K}$ & - & 15.10 & I $15.29 \mathrm{~K}$ \\
\hline $7 \mathrm{c}$ & $7 / 8$ & K 96.7 I & I $78.6^{\text {bee }} \mathrm{K}$ & - & 12.64 & I $12.64 \mathrm{~K}$ \\
\hline $7 d$ & $9 / 7$ & K $93.8 \mathrm{I}$ & I $76.9^{\mathrm{b}} \mathrm{SmC} 64.8 \mathrm{~K}$ & 12.1 & 18.69 & I $4.19 \mathrm{SmC} 10.88 \mathrm{~K}$ \\
\hline $7 \mathrm{e}$ & $7 / 10$ & K $102.5 \mathrm{I}$ & I $75.7^{\mathrm{b}} \mathrm{SmC} 71.2 \mathrm{~K}$ & 4.5 & 13.40 & I $2.81 \mathrm{SmC} 11.79 \mathrm{~K}$ \\
\hline $7 f$ & $9 / 9$ & K 91.9 I & I $82.5^{\mathrm{b}} \mathrm{SmC} 58.1 \mathrm{~K}$ & 24.4 & 12.79 & I $3.01 \mathrm{SmC} 6.15 \mathrm{~K}$ \\
\hline $7 \mathrm{~g}$ & $9 / 10$ & K 100.4 I & I $83.3^{\mathrm{b}} \mathrm{SmC} 68.2 \mathrm{~K}$ & 15.1 & 16.67 & I $3.66 \mathrm{SmC} 11.82 \mathrm{~K}$ \\
\hline & & & & $\mathrm{Ar}=4$ & ${ }_{6} \mathrm{H}_{4} \mathrm{OR} ;$ & \\
\hline $8 \mathrm{a}$ & $7 / 7$ & K 134.7 I & I $125.8^{\mathrm{a}, \mathrm{b}} \mathrm{N} 118.0 \mathrm{~K}$ & 7.8 & 6.26 & $\mathrm{I}^{\mathrm{f}} \mathrm{N} 8.36 \mathrm{~K}$ \\
\hline $8 b$ & $7 / 8$ & K 138.4 I & I $134.3^{\mathrm{b}} \mathrm{N} 120.2 \mathrm{~K}$ & 14.1 & 13.91 & I $0.67 \mathrm{~N} 13.53 \mathrm{~K}$ \\
\hline $8 \mathrm{c}$ & $7 / 9$ & K 133.5 I & I $120.0^{\mathrm{b}} \mathrm{N} 116.7 \mathrm{~K}$ & 3.3 & 15.01 & I 0.087 N $15.66 \mathrm{~K}$ \\
\hline $8 \mathrm{~d}$ & $7 / 10$ & K 137.8 I & I $132.5^{\mathrm{b}} \mathrm{N} 121.4 \mathrm{~K}$ & 11.1 & 11.94 & I $0.72 \mathrm{~N} 11.01 \mathrm{~K}$ \\
\hline
\end{tabular}

Scan rate: $10{ }^{\circ} \mathrm{C} \mathrm{min}^{-1}$ for all samples; $\mathrm{K}=$ Crystal phase; $\mathrm{SmC}=$ Smectic $\mathrm{C}$ phase and $\mathrm{N}=$ Nematic phase. ${ }^{\mathrm{a}}$ Transition temperatures were obtained from POM analyze. ${ }^{b}$ Monotropic behavior. ${ }^{c}$ Enthalpies values (second heating/cooling stage) were determined from crystal phase to LC phase or isotropic phase for compound 6. ${ }^{\mathrm{d}} \mathrm{Heating}$ for $\mathbf{5 a - c}$ and cooling for 7a-g and 8a-d. ${ }^{\mathrm{e}}$ Upon slow cooling the samples crystallizes. Upon fast cooling the sample displayed a very short range of the $\mathrm{SmC}$ phase during the crystallization process. ${ }^{\mathrm{f}}$ Enthalpy value not determined.

liquid crystals. The singularity points are defects in the structure where two or four brushes meet. In the smectic $\mathrm{C}$ phase, only singularities with four brushes are observed (Figures 1e and 1f). Nematic phase may also showed singularities with two brushes (Figures 1a and 1b).

The homologous series 8a-d exhibited a thread-like texture when the sample was sandwiched between two glass plates that had not been rubbed or treated (Figure 1d). This texture is usually observed in thin samples placed between two crossed polarizers. The dark lines, the so-called threads, are line singularities, which either connect two point defects or form closed loops. The planar thread-like texture is characteristic of liquid-crystalline nematic phase.
Compounds 5a-c displayed enantiotropic nematic phase whereas compound $\mathbf{6}$ is a non-mesomorphic compound. The non-liquid crystal 6 melts at $129.5{ }^{\circ} \mathrm{C}$ from its crystalline state to an isotropic liquid and it crystallizes at $116.1^{\circ} \mathrm{C}$ without any trace of a LC mesophase (Figures 1c and 2). The lack of LC behavior for this compound is probably related to the geometrical anisotropy when the napthyl group is changed to phenyl group.

Compounds belong to $\mathbf{5 a}$-c ceries showed enantiotropic behavior when analyzed by POM. However, the DSC traces of the $\mathbf{5 a}$ did not exhibit $\mathrm{K} \rightarrow \mathrm{N}$ on heating and whereas $\mathbf{5 c}$ did not exhibit $\mathrm{I} \rightarrow \mathrm{N}$ on cooling (Figure 2). For example, on heating, the sample 5a enters into the nematic phase 


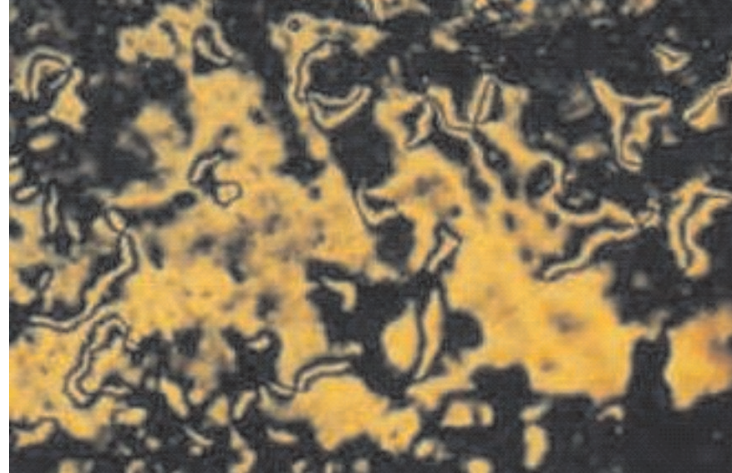

(a)

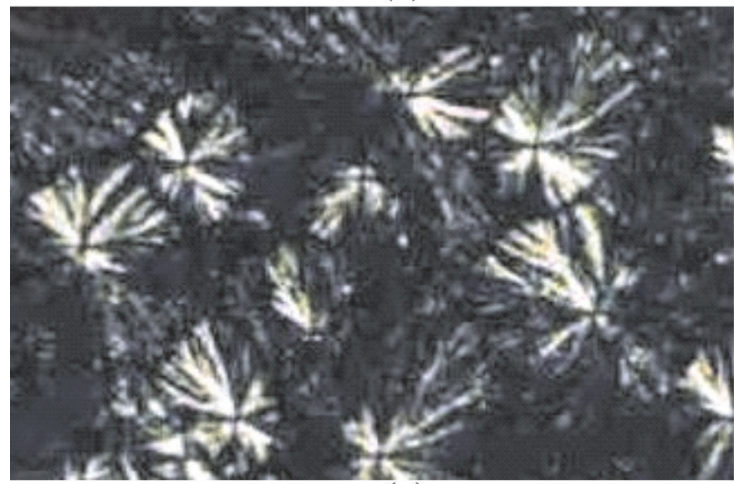

(c)

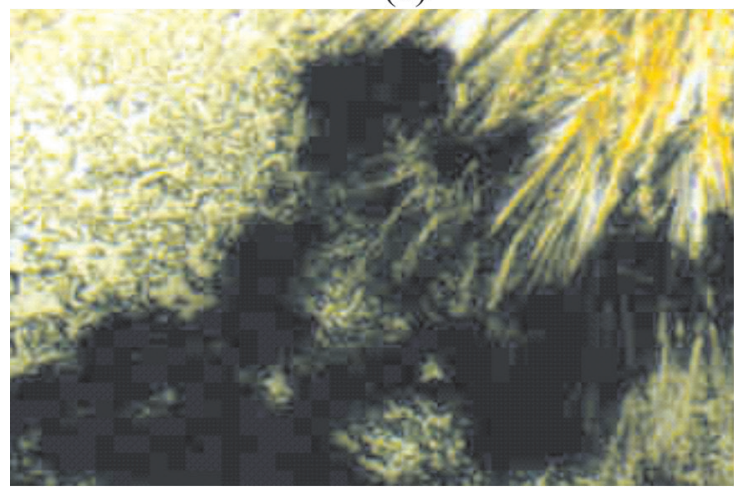

(e)

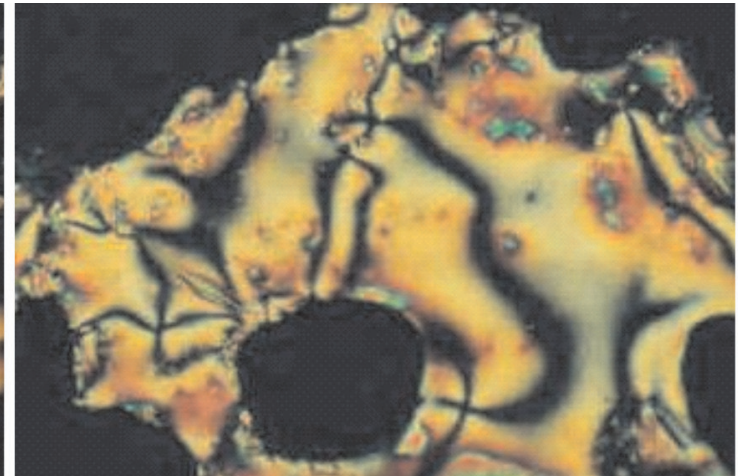

(b)

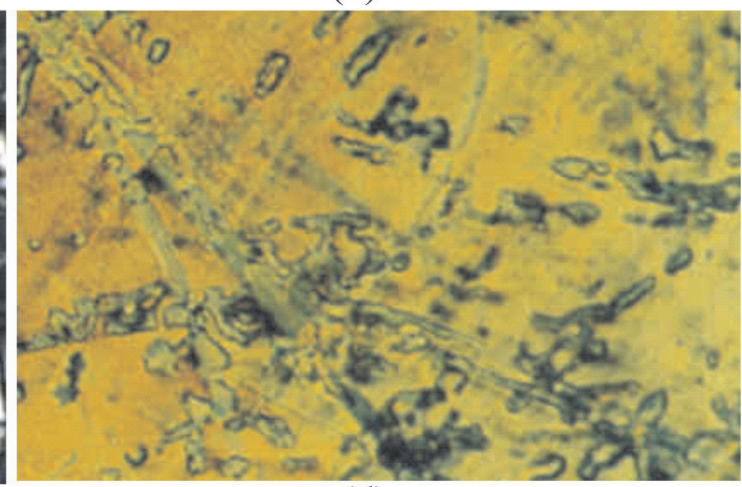

(d)

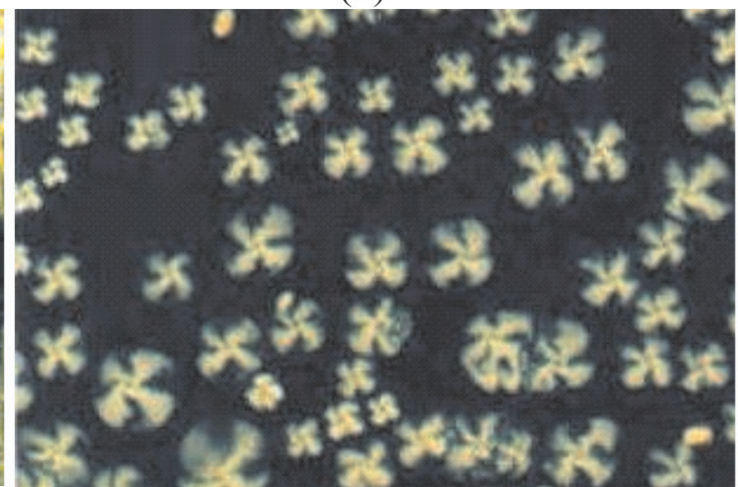

(f)

Figure 1. Polarizing optical photomicrographs (10x). (a) The planar thread-like texture on cooling of $\mathbf{5 a}\left(141.7^{\circ} \mathrm{C}\right)$; (b) schlieren texture of $\mathbf{5 b}$ on heating $\left(145.8^{\circ} \mathrm{C}\right)$; (c) crystal phase ("pom-pom" texture) of $\mathbf{6}$ on cooling $\left(107.8^{\circ} \mathrm{C}\right)$; (d) nematic planar texture of $8 \mathbf{d}$ on cooling $\left(129.7^{\circ} \mathrm{C}\right)$; (e) the coexisting of smectic $\mathrm{C}$ and crystal phase of $\mathbf{7 d}$ on cooling $\left(67.2^{\circ} \mathrm{C}\right.$ ); (f) the schlieren texture of the smectic $\mathrm{C}$ phase (color-four-fold rosette and black-isotropic liquid) of $7 \mathbf{g}$ on cooling $\left(83.0^{\circ} \mathrm{C}\right)$.

at $144.5^{\circ} \mathrm{C}$ and melts to an isotropic liquid at $148.0^{\circ} \mathrm{C}$. The range of temperature for the mesophase is small for $\mathbf{5 a}\left(\Delta \mathrm{T}=3.5^{\circ} \mathrm{C}\right)$ and large for $\mathbf{5 b}\left(\Delta \mathrm{T}=16.1^{\circ} \mathrm{C}\right)$ and $\mathbf{5 c}$ $\left(\Delta \mathrm{T}=8.4^{\circ} \mathrm{C}\right)$. On cooling, the mesophase range follows the same tendency. They are larger for compounds $\mathbf{5 b}$ $\left(\Delta \mathrm{T}=16.7^{\circ} \mathrm{C}\right)$ and $\mathbf{5 c}\left(\Delta \mathrm{T}=18.8^{\circ} \mathrm{C}\right)$ than for $\mathbf{5 a}$ $\left(\Delta \mathrm{T}=6.0^{\circ} \mathrm{C}\right)$, while the transition enthalpies (Table 1) for the isotropic to nematic transition of the 5a-c are rather low. These values are consistent with a less ordered nematic mesophase.

The third homologous series $\mathbf{7 a - g}$ displayed a monotropic smectic $\mathrm{C}$ mesophase only for the superior members $\mathbf{7 c - g}$. For the first and second members (7a and 7b) of this series no mesophase was observed. While the next member 7c exhibited a monotropic smectic $\mathrm{C}$ phase. The smectic $\mathrm{C}$ phase appeared only under fast cooling and the mesophase range was too short to be determined under these conditions. On cooling, $7 \mathbf{c}$ crystallizes at $78.6{ }^{\circ} \mathrm{C}$. The broken-fan focal conic texture of the SmC phase appears during the crystallization process. The broken-fan can be visualized simultaneously with the crystals and they disappear very fast. This situation makes it impossible to get some information about the range of this mesophase. Upon slow cooling, no traces of the mesophase were detected and 

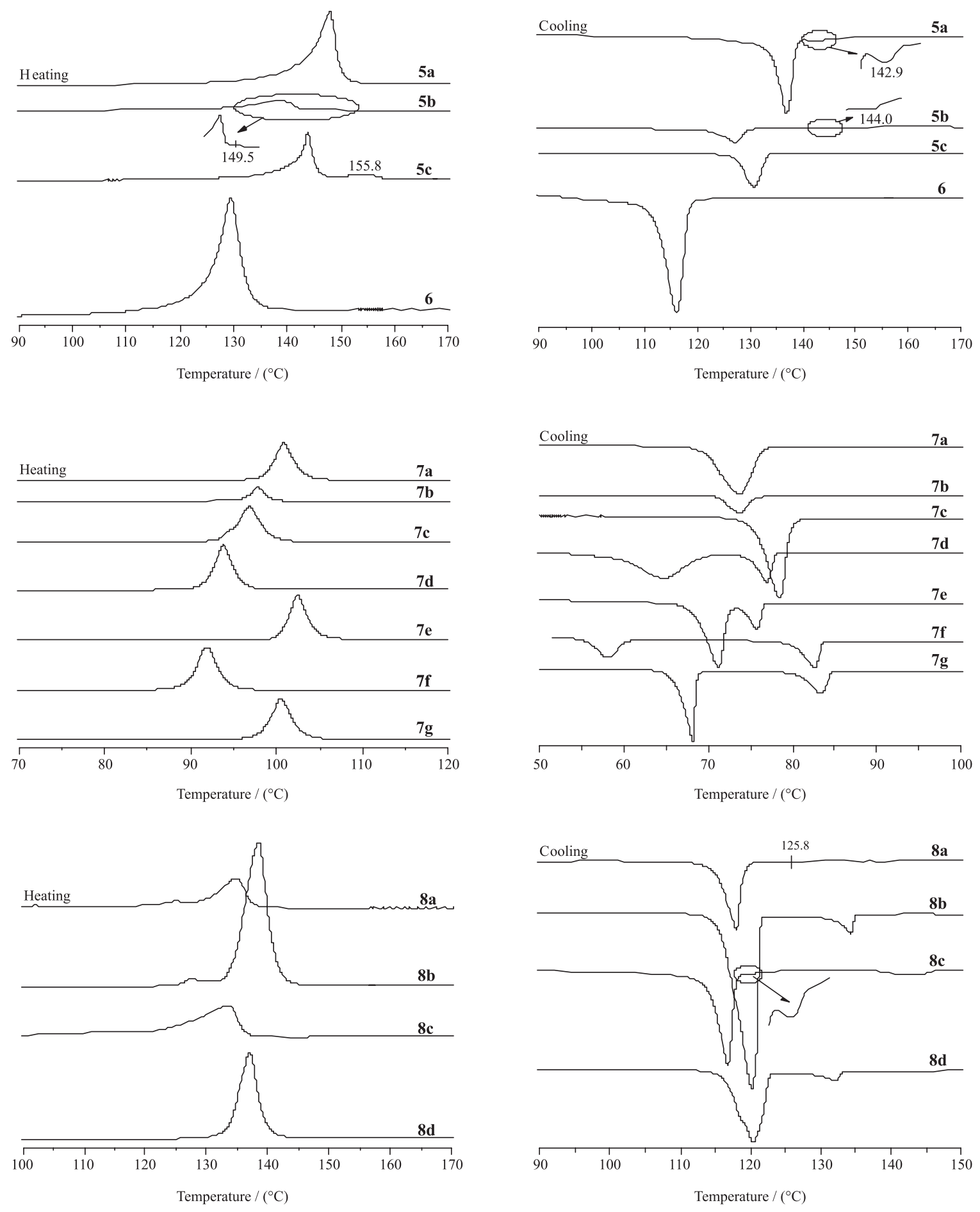

Figure 2. DSC thermograms of compounds 5a-c, 6, 7a-g and $8 \mathbf{a}-\mathbf{d}$ on $2^{\text {nd }}$ cycle at $10{ }^{\circ} \mathrm{C} \mathrm{min}^{-1}$.

observed. For the superior members $\mathbf{7 d - g}$ the range of the monotropic SmC phase was determined. The DSC traces are shown in Figure 2 and the thermal data for this series is shown in Table 1. The melting points of these compounds display a regular tendency if we compare them in pairs. The compounds containing odd carbon atoms in their alkyl chains melt at higher temperatures than the next member having an even carbon in the alkyl chains. For instance, the melting points of $\mathbf{7 a}, 7 \mathrm{c}, 7 \mathrm{e}$ and $\mathbf{7 g}$ are higher than $\mathbf{7 b}$, $\mathbf{7 d}$ and $7 \mathbf{f}$. Figure $3 \mathrm{a}$ shows the dependence of the melting points on the number of carbon atoms in the alkyl tail for the 7a-g homologues. Also, from Figure 3a it is possible to see that the melting point decreases with the increase of $n$ in the alkyl chain on going from $\mathbf{7 a}$ to $\mathbf{7 d}$. The melting point 
for 7e doesn't follow the tendency, and it is higher than 7d. However it is possible to establish the same correlation between the melting point and the length of the terminal $n$-alkyl chain to the last three members of this series. For instance $7 \mathbf{e}$ with an odd number of carbon atoms in its alkyl chain has a higher melting point than $\mathbf{7 f}$. The melting points of compounds 7e-g display an odd-even effect as seen with the four first compounds. The deviation observed jumping from 7a-d to 7e-g may be associated with the increase in the molecular weight of the latter compounds. The tendency observed in both groups of the LC series 7a-d and 7e-g related to the lowering of the melting point is probably a manifestation of the lipophilic effect as the length of the alkyl chains increase. The transition enthalpies of the isotropic to smectic transitions of $\mathbf{7 d}-\mathbf{g}$ are higher than for both 5a-c and 8a-d. The enthalpy value suggests a more ordered phase going from isotropic to smectic phase compared to compounds 5a-c or $\mathbf{8 a - d .}$

In general, as the length of the alkyl chains increases the mesophase range becomes wider, especially with respect to smectic phase; the opposite is observed for the nematic phase (see discussion for 8a-d below). The reduction of the length of the alkyl chain may be responsible for the absence of the mesophase. A delicate balance between many structural parameters favors the appearance of the mesophase for the intermediate compounds $\mathbf{7 c - g}$. The inversion of the ester group and the insertion of a methylene unit between the isoxazolyl and carboxyl groups are other two factors that should have considered when we compare the compounds 7a-g with $\mathbf{5 a - c}$ and $\mathbf{6}$.

In contrast to the compounds $\mathbf{5 a - c}$, the homologous series 8a-d displayed monotropic nematic mesophase with planar thread-like texture. The thermal, optical and thermodynamic data of these compounds are compiled in Table 1. All compounds displayed similar thermal behavior. The DSC traces are shown in Figure 2. For 8a and 8c $\left(\Delta \mathrm{T}=7.8{ }^{\circ} \mathrm{C} ; \Delta \mathrm{T}=3.3{ }^{\circ} \mathrm{C}\right)$ the mesophase range was smaller than for $\mathbf{8 b}$ and $8 \mathbf{d}\left(\Delta \mathrm{T}=14.1{ }^{\circ} \mathrm{C} ; \Delta \mathrm{T}=11.1{ }^{\circ} \mathrm{C}\right)$. The melting points of this series have the same tendency observed to the series 7a-g. The LCs $8 \mathbf{a}$ and $\mathbf{8 c}$ melt at lower temperature than $\mathbf{8 b}$ and $\mathbf{8 d}$. The LCs with odd carbon atoms in the alkyl group, considering R plus R', melt ca. $4{ }^{\circ} \mathrm{C}$ above the LCs containing even carbon atoms on their terminal tails. The transition temperatures $\mathrm{I} \rightarrow \mathrm{N}$ obtained on cooling exhibited the same behavior. For example, on cooling, $\mathbf{8 b}$ and $\mathbf{8 d}$ enter into the nematic phase at higher temperature than $\mathbf{8 a}$ and $\mathbf{8 c}$.

The usual even-odd alternations of temperature range of the crystal-isotropic phase and of the isotropic-nematic phase transition are observed. For the odd number of the carbon atoms the mesophase range is higher than for the even number of the carbon atoms in the alkyl tail. Figure $3 \mathrm{~b}$ shows the dependence of the transition temperatures on the number of carbon atoms in the alkyl tail for the 8a-d series. The tendency observed upon heating of the melting points is similar to the transition temperatures $\mathrm{I} \rightarrow \mathrm{N}$ observed on cooling process. The compounds that have an odd number of carbon atoms exhibit higher values than for those with an even number of carbon atoms. This can be seen in Figure 3b: the superior line is related to the melting point and inferior line is associated with the temperature when the compounds 8a-d enter into nematic phase. It should be noted that, when compared with $\mathbf{8 b}$ and $\mathbf{8 d}$, the enthalpy values for these isotropic-nematic transitions of $\mathbf{8 c}$ also showed the odd-even effect. The enthalpy value of the 8a was too small to be detected by DSC. The phase transition for this member was observed with a polarizing microscope. However the values for the compounds with odd carbon atoms in the alkyl tail, $\mathbf{8 b}$ and $\mathbf{8 d}$, are larger than the conventional nematic $\leftrightarrow$ isotropic transition enthalpies $\left(<0.50 \mathrm{kcal} \mathrm{mol}^{-1}\right)$ for calamitic liquid crystals. In addition, these enthalpy values for compounds $8 \mathbf{8}-\mathbf{d}$ are higher than series 5a-c. This may be indicating that relatively strong intermolecular interactions might exist in its nematic phase and could be attributed to the inversion of the carboxylate group between $\mathbf{5 a - c}$ and $\mathbf{8 a - d}$.

A theoretical study was performed in order to understand the phase behavior and correlate it to the structural features of these compounds. We selected the LC compounds $\mathbf{5 b}$, $7 \mathbf{b}$ and $\mathbf{8 c}$ as a representative of this study and their energy and its corresponding geometry of all model systems were obtained by full optimization without any constraint. The calculation was performed with the GAUSSIAN $98^{10}$ program using the B3LYP hybrid functional, ${ }^{10}$ employing a 6-31G(d,p) basis set.

The molecular shape of a compound has a critical effect on its liquid-crystalline behavior. Two facts are important and need to discuss relating to the mesomorphic behavior of the calamitic liquid crystals (rod-like mesogen). First, the linear-shape of the calamitic LC changes to a bentshape with the introduction of five-membered heterocycles into the center of the mesogenic core. ${ }^{11}$ The bent-shape is a consequence of the relative position of the substituent bonded at the heterocyclic group. So, the deviation of linearity is an important structural parameter that should be taken into account. Second, the 3,5-disubstitued isoxazoline ring has two non-coplanar aromatic groups bonded at 3-and 5-position of the isoxazoline ring. The non-linearity of the isoxazoline ring along with the non-coplanarity of the two aryl groups located at $\mathrm{C}_{3}$ and $\mathrm{C}_{5}$ on the heterocyclic ring are determine whether a stable liquid-crystalline phase forms. To minimize this unfavorable disposition of the groups in 
(a)

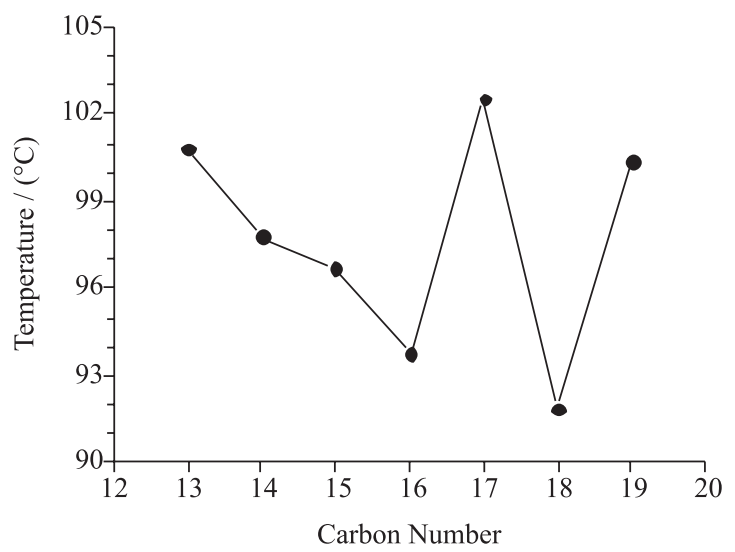

(b)

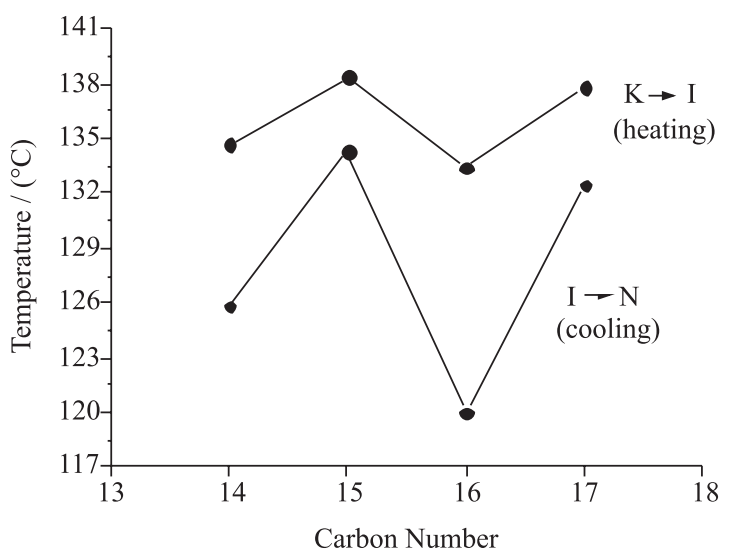

Figure 3. (a) Plot of melting point against the number of carbon atoms of the homologues 7a-g. (b) Plot of transition temperatures against the number of carbon atoms $(n)$ in the alkoxy chain of the compounds 8a-d Melting points (above); I-N transition temperature (below, on cooling).

the 3- and 5-carbon atom of the isoxazoline ring, the final central core must be as long as possible and possess high polarizability. In this way, the potential LC materials are reached through an "elongating molecular strategy" from the isoxazoline intermediates. This elongation builds off the rigid isoxazoline core to form a more polarizable and mesogenic one.

The mesomorphic behavior found in this work is due to the presence of the long aromatic moiety laterally bonded to the isoxazoline ring. However, in some cases the molecular dimensions (length-to-breadth ratio) of the aromatic moiety are not sufficient to overcome the non-coplanarity of the aryl group connected on the isoxazoline ring. In this situation no mesophase or unstable mesophase (i.e, monotropic behavior) appears. By changing the hybridization of the $\mathrm{C}_{4}$ and $\mathrm{C}_{5}$ carbon atoms of the isoxazolinic system the liquid-crystalline state forms vigorously. Our previous work showed that oxidation of the isoxazoline to isoxazol ring yield LC materials with a large enantiotropic nematic mesophase. ${ }^{6}$ The appearance of stable mesophase in isoxazol systems ${ }^{12}$ is due to the substitution of a tetrahedral to planar carbon in the heterocyclic so that the two aryl and the isoxazoyl groups are coplanar and thus fully conjugated.

Table 2 shows the three lowest-energy conformations of the $\mathbf{5 b}, \mathbf{7 b}$ and $\mathbf{8 c}$ compounds. The other conformations of these compounds are not energetically favorable (by more than $1.00 \mathrm{kcal} \mathrm{mol}^{-1}$ ) and these contributions can be neglected because they are local minima. The energy profile of the conformational population largely favors the conformation shown in Table 2. Therefore, we focused our analysis on the lowest-energy conformations so that the high energy conformations are not considered during this study. Modeling of these structures allows certain interesting conclusions to be drawn concerning their mesomorphic behavior. The distance between the oxygen of the carboxylate group and the hydrogen $\left(\mathrm{O}_{45}-\mathrm{H}_{42}\right)$ for the 5b, $\mathrm{O}_{44}-\mathrm{H}_{39}$ for the $\mathbf{7 b}$ and $\mathbf{8 c}$ are 2.37, 2.46 and $2.45 \AA$, respectively. These values reveal a weak hydrogen bond in these conformers and they supported that this interaction is important to maintain the conformers in their lowest-energy state. As we can see in the Figure 4a, the hydrogen atom bonded to carbon 4 in the isoxazolinic ring shows a more positive charge than the others, interacting to the carboxylic oxygen as a weak hydrogen bond.

The dipole moment of these conformers may also play an additional role in the stabilization of the mesomorphic state. Compound $\mathbf{5 b}$ has the lowest value whereas $\mathbf{8 c}$ presents the highest value. A probable conclusion about this data is that compounds having the smallest molecular dipole values display enantiotropic behavior as we can see from the data for series 5a-c (Table 1). On the other hand, compounds belonging to the series $7 \mathbf{a}-\mathbf{g}$ and $\mathbf{8 a - d}$ having high values of the molecular dipole show monotropic LCs. A preliminary conclusion from the modeling data is that a large increase in the molecular dipole does not favor the formation of an enantiotropic mesophase (Table 1). However it is important to point out that monotropic behavior, or the absence of a mesogenic state, observed in the series 7a-g and 8a-d is mainly due to the deviations of the coplanarity between aromatic molecular segments connected by the polar isoxazoline ring.

The dihedral angle of the $\mathbf{5 b}, \mathbf{7 b}$ and $\mathbf{8 c}$ conformers was selected and they are listed in Table 2. The theoretical calculations reveal that rotation about $\mathrm{C}_{1}-\mathrm{C}_{44}$ and $\mathrm{C}_{1}-\mathrm{C}_{41}$ bond of the compounds $\mathbf{5 b}, \mathbf{7 b}$ and $\mathbf{8 c}$, respectively, play an important role on their corresponding liquid crystalline behavior. The rotation about the $\mathrm{C}_{1}-\mathrm{C}_{44}$ bond of $\mathbf{5 b}$ yielded the more stable conformer which is separated by more than $1.00 \mathrm{kcal} \mathrm{mol}^{-1}$ from the another unstable conformer of $\mathbf{5 b}$ (not shown). The angle between two planes (right and left) of the molecule is about $135.9^{\circ}$. The dihedral angle 
$\mathrm{O}_{2}-\mathrm{C}_{1}-\mathrm{C}_{44}-\mathrm{O}_{45}$ to the most stable conformation is $116.1^{\circ}$. This molecular arrangement favors mesophase formation probably due to the tendency of the polar mesogenic phase to self-assemble during the melting or passing from the isotropic to mesogenic state.

The insertion of methylene unit between the isoxazoline ring and carboxyl group changes the relative disposition of the two planes in the conformers of $\mathbf{7 b}$ and $\mathbf{8 c}$. As we can see in Table 2 the conformers $\mathbf{7 b}$ and $\mathbf{8 c}$ present two distinct planes connected by the $\mathrm{C}_{1}-\mathrm{C}_{41}$ bond. These planes are slightly collinear, twisted and non-coplanar. The estimated angles between these planes are $30.47^{\circ}$ for $7 \mathbf{b}$ and $28.45^{\circ}$ for $8 \mathbf{c}$ (Figure $4 b, c)$. The dihedral angles $\mathrm{O}_{2}-\mathrm{C}_{1}-\mathrm{C}_{41}-\mathrm{O}_{42}$ to the most stable conformation of the $\mathbf{7 b}$ and $\mathbf{8 c}$ are $163.5^{\circ}$ and $163.3^{\circ}$, respectively. This arrangement favors the shortweak hydrogen bond interaction between $\mathrm{O}_{44}-\mathrm{H}_{39}$ atoms in both rotamers. The conclusion that can be drawn from these data is that the methylene unit, as described above,

(a)

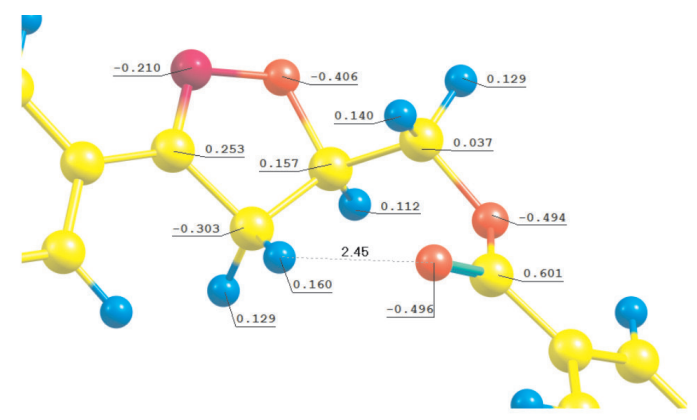

(b)

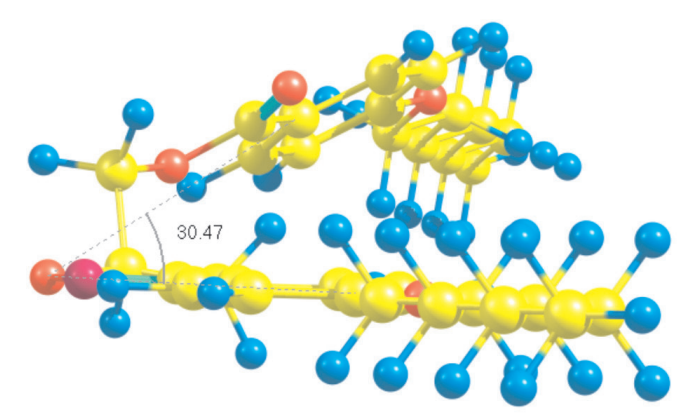

(c)
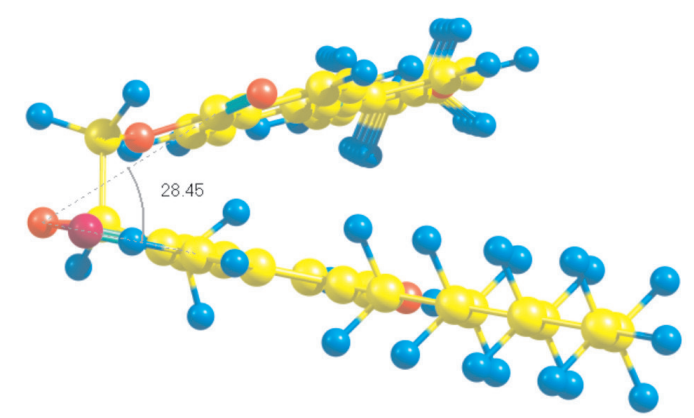

Figure 4. (a) Central core of the 8c molecule showing the Mülliken charges and distance between oxygen of the carboxylate group and the hydrogen (2.45 $\AA$, dotted line). (b) and (c) Diedral angle between molecular planes of the conformers: $30.47^{\circ}$ for $7 \mathrm{~b}$ and $28.45^{\circ}$ for $8 \mathrm{c}$. produces two distinct planes which disfavor the molecular interaction in the liquid-crystalline state. The electrostatic interaction and dispersion interaction (van der Waals forces, $\pi$-stacking effects, etc) cannot compensate for the structural constraints that are imposed by the methylene group in the 5-(hydroxymethyl)-3-aryl-2-isoxazoline ring.

\section{Experimental}

\section{Materials}

Ethanol, diethyl ether, $p$-bromobenzoic acid, copper(I) iodide $(\mathrm{CuI})$, triphenylphosphine $\left(\mathrm{PPh}_{3}\right)$, 4 -( $N, N$-dimethylamino)pyridine (DMAP) and 1,3-dicyclohexylcarbodiimide (DCC) were used without further purification from Aldrich. The $p$ - $n$-alkoxybenzoic acid and 1-alkoxy-4-ethynylbenzene were prepared according to references 7 and 8 , respectively. Bis(triphenylphosphine)palladium (II) chloride $\left[\mathrm{PdCl}_{2}\left(\mathrm{PPh}_{3}\right)_{2}\right]$ was prepared following the procedure reported in reference 13. Triethylamine $\left(\mathrm{Et}_{3} \mathrm{~N}\right)$ was distilled over potassium hydroxide. Tetrahydrofuran (THF) was dried over sodium metal-benzophenone and distilled immediately before use. Anhydrous sodium sulphate $\left(\mathrm{Na}_{2} \mathrm{SO}_{4}\right)$ was used to dry organic extracts.

\section{Characterization}

Nuclear magnetic resonance spectra were obtained on a Varian $300 \mathrm{MHz}$ instrument. Chemical shift are given in parts per million $(\delta)$ and are referenced from tetramethylsilane (TMS). GC-MS spectra are obtained using a Varian Saturn 2100T CG-MS equipped with a 100 meter CP Sil Pona CB $(0.25 \mathrm{~mm})$ column. The column temperature is started at $50{ }^{\circ} \mathrm{C}$ and is gradually ramped to $230{ }^{\circ} \mathrm{C}\left(15^{\circ} \mathrm{C} \mathrm{min}-1\right)$ until the end of the run. Infrared spectra were recorded on a Perkin-Elmer Spectrum One FTIR Spectrometer Instruments using $\mathrm{NaCl}$ plates in case of solids (nujol dispersions) and as thin film supported between $\mathrm{NaCl}$ plates in case of liquids and are reporter as wavenumber $\left(\mathrm{cm}^{-1}\right)$. Elemental analyses were performed on a Perkin-Elmer model 2400 instrument. All new compounds 5a-c, 6, 7a-g and 8a-d gave satisfactory spectral, MS data and elemental analysis. The DSC analyses were obtained on a DSC 2910 TA Instruments.

\section{Thermal characterization}

Melting points, thermal transitions and mesomorphic textures were taken using an Olympus BX41 microscope equipped with a Mettler Toledo FP82 Hot Stage FP90 
Table 2. Lowest-energy conformations for the $\mathbf{5 b}, \mathbf{7 b}$ and $\mathbf{8 c}$ compounds. The alkyl groups have been omitted for clarity

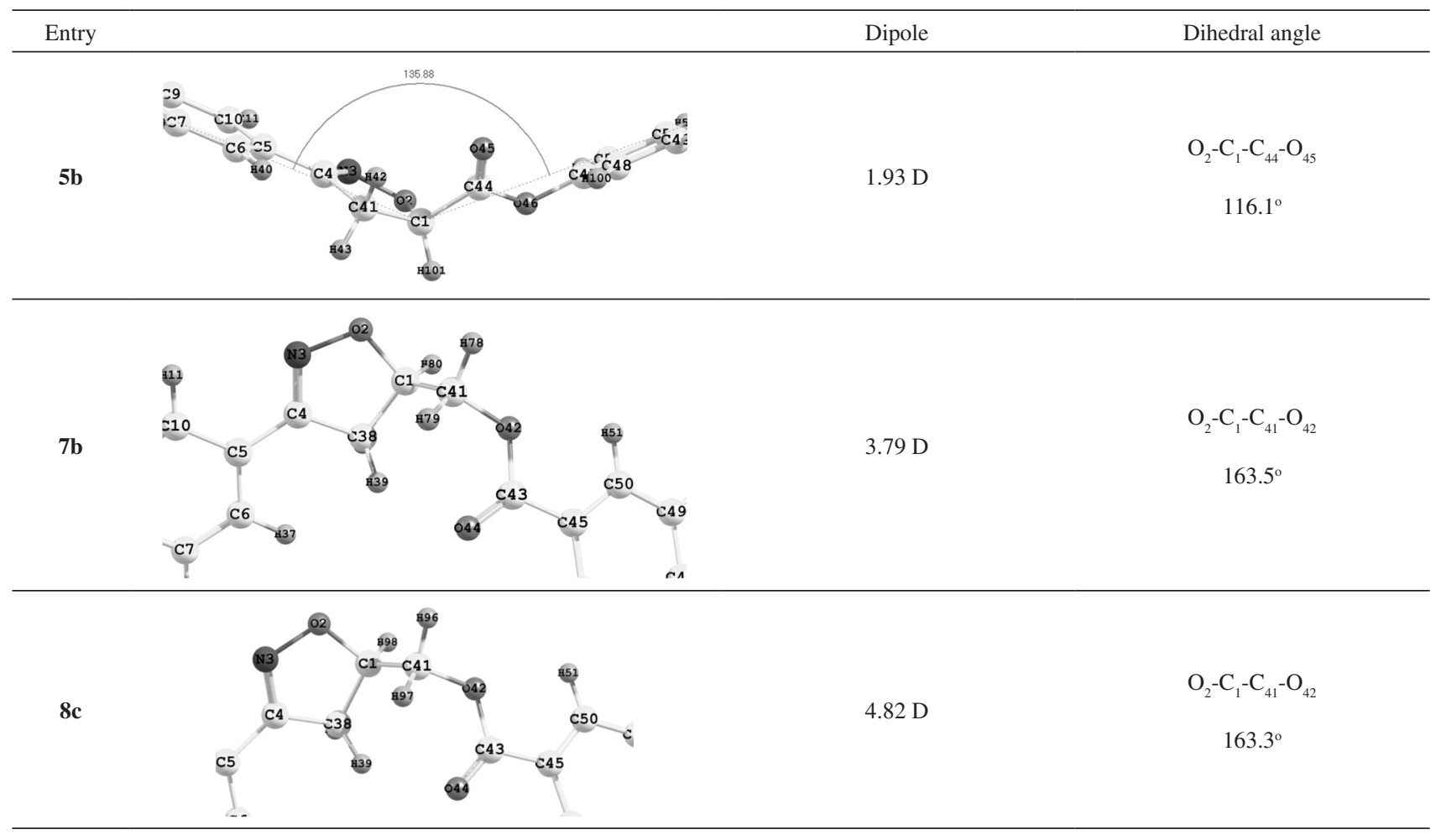

Central Processor. The rate of heating or cooling was $10{ }^{\circ} \mathrm{C} \min ^{-1}$.

\section{Theoretical calculations}

The energy and its corresponding geometry of all model systems were obtained by full optimization without any constraint. The calculation was performed with the GAUSSIAN $98^{10}$ program using the B3LYP hybrid funcional, employing a 6-31G(d,p) basis set.

\section{Synthesis}

The 3-arylisoxazolyl-5-carboxylic acid (1a-d) and 5-(hydroxymethyl)-3-aryl-2-isoxazoline (2a-d) were prepared according to our previous report. ${ }^{6}$

\section{4-[(6-Octyloxy-2-naphthyl)ethynyl]phenol (3)}

This compound was prepared according to previous report. ${ }^{6,8} 4$-[(4-Octyloxyphenyl)ethynyl]phenol (4) was obtained by procedures similar to that used to prepare compound $\mathbf{3}$ (Yield: $300 \mathrm{mg}, 34 \%$, three steps); white solid; mp $69.1{ }^{\circ} \mathrm{C}$; IR $v_{\text {max }} / \mathrm{cm}^{-1}: 2925,2855,1727,1466,1377$, $1251,1182,898,876,829,721,666$; ${ }^{1} \mathrm{H}$ NMR (300 MHz, $\left.\mathrm{CDCl}_{3}\right) \delta 0.88\left(\mathrm{~m}, 3 \mathrm{H}, \mathrm{CH}_{3}\right), 1.39\left(\mathrm{~m}, 10 \mathrm{H},\left(\mathrm{CH}_{2}\right)_{5}\right), 1.78$ $\left(\mathrm{m}, 2 \mathrm{H}, \mathrm{C}_{2} \mathrm{CH}_{2} \mathrm{O}\right), 3.97\left(\mathrm{t}, 2 \mathrm{H}, \mathrm{CH}_{2} \mathrm{O}, J 6.6 \mathrm{~Hz}\right), 6.80(\mathrm{~d}$, $2 \mathrm{H}, \mathrm{Ar}, J 8.4 \mathrm{~Hz}), 6.86$ (d, 2H, Ar, J $8.4 \mathrm{~Hz}), 7.40$ (m, 4H,
Ar); ${ }^{13} \mathrm{C}$ NMR (75 MHz, $\left.\mathrm{CDCl}_{3}\right) \delta 14.1,22.6,26.0,29.1$, $29.2,29.3,31.8,68.1,87.7,88.0,114.5,115.4,115.5$, 115.9, 132.8, 133.0, 155.5, 159.0.

4-[(6-Alkyloxy-2-naphthyl)ethynyl]phenyl 3-(4-alkyloxyphenyl)-4,5-dihydroisoxazole-5-carboxylate (5a-c)

These compounds were prepared according to the protocol reaction DCC/DMAP/DCM following the experimental procedure described in reference 6 .

\section{Representative data for $\mathbf{5 a}$}

Yield $115 \mathrm{mg}$, 70\%; white solid; mp $144.5^{\circ} \mathrm{C}$; Anal. Found: C, 78.48; H 7.58, N 2.07; calc. for $\mathrm{C}_{43} \mathrm{H}_{49} \mathrm{NO}_{5}$ : C, $78.27 ; \mathrm{H}, 7.48 ; \mathrm{N}, 2.12 \%$; IR $v_{\max } / \mathrm{cm}^{-1}: 2924,2854,1763$, 1596, 1464, 1378, 1224, 1045, 897, 859, 818, 722, 666; ${ }^{1} \mathrm{H} \mathrm{NMR}\left(300 \mathrm{MHz}, \mathrm{CDCl}_{3}\right) \delta 0.88\left(\mathrm{~m}, 6 \mathrm{H},\left(\mathrm{CH}_{3}\right)_{2}\right), 1.38$ $\left(\mathrm{m}, 18 \mathrm{H},\left(\mathrm{CH}_{2}\right)_{9}\right), 1.82\left(\mathrm{~m}, 4 \mathrm{H},\left(\mathrm{CH}_{2} \mathrm{CH}_{2} \mathrm{O}\right)_{2}\right), 3.75(\mathrm{~m}$, $2 \mathrm{H}, \mathrm{C}_{2} \mathrm{CH}$ ), 3.98 (t, J $6.6 \mathrm{~Hz}, 2 \mathrm{H}, \mathrm{CH}_{2} \mathrm{O}$ ), 4.07 (t, J 6.6 $\left.\mathrm{Hz}, 2 \mathrm{H}, \mathrm{CH}_{2} \mathrm{O}\right), 5.37\left(\mathrm{dd}, J 7.2,11.1 \mathrm{~Hz}, 1 \mathrm{H}, \mathrm{CH}_{2} \mathrm{CH}\right)$, $6.92(\mathrm{~d}, J 8.7 \mathrm{~Hz}, 2 \mathrm{H}, \mathrm{Ar}), 7.14$ (m, 4H, Ar), $7.50-7.72$ (m, 7H, Ar), 7.96 (s, 1H, Ar); ${ }^{13} \mathrm{C} \mathrm{NMR} \mathrm{(75} \mathrm{MHz,} \mathrm{CDCl}_{3}$ ) $\delta$ 14.0, 14.1, 22.5, 22.6, 25.9, 26.1, 28.9, 29.0, 29.1, 29.2, 29.3, 31.7, 31.8, 39.2, 68.0, 68.1, 77.7, 87.9, 90.4, 106.5, $114.7,117.6,119.7,120.5,121.3,121.6,126.8,128.3$, $128.5,128.8,129.2,131.3,132.7,134.2,149.9,155.6$, 157.9, 161.0, 168.5; EI-MS: $m / z$ 530, 468, 426, 371, 355, 
304, 290, 279, 258, 233, 218 (100), 190, 129, 128, 116 and 91.

4-[(4-Octyloxyphenyl)ethynyl]phenyl 3-(4-heptyloxyphenyl)-4,5-dihydroisoxazole-5-carboxylate (6)

This compound was obtained by procedures similar to those used to prepare compound 5a. Yield: $110 \mathrm{mg}, \mathbf{5 0 \%}$; white solid; mp $129.5^{\circ} \mathrm{C}$; Anal. Found: C, 76.58; H 7.68, $\mathrm{N} 2.42$; calc. for $\mathrm{C}_{39} \mathrm{H}_{47} \mathrm{NO}_{5}$ : C, 76.82; H, 7.77; N, 2.30\%; IR $v_{\max } / \mathrm{cm}^{-1}: 2924,2855,1765,1595,1467,1378,1224$, $1043,896,859,820,722,666 ;{ }^{1} \mathrm{H}$ NMR (300 MHz, $\mathrm{CDCl}_{3}$ ) $\delta 0.88\left(\mathrm{~m}, 6 \mathrm{H},\left(\mathrm{CH}_{3}\right)_{2}\right), 1.40\left(\mathrm{~m}, 18 \mathrm{H},\left(\mathrm{CH}_{2}\right)_{9}\right), 1.78(\mathrm{~m}, 4 \mathrm{H}$, $\left.\left(\mathrm{CH}_{2} \mathrm{CH}_{2} \mathrm{O}\right)_{2}\right), 3.75\left(\mathrm{~m}, 2 \mathrm{H}, \underline{\mathrm{CH}}_{2} \mathrm{CH}\right), 3.98\left(\mathrm{~m}, 4 \mathrm{H}, \mathrm{CH}_{2} \mathrm{O}\right)$, $5.37\left(\mathrm{dd}, 1 \mathrm{H}, \mathrm{CH}_{2} \mathrm{C} \underline{\mathrm{H}}, J 7.2,10.5 \mathrm{~Hz}\right), 6.86(\mathrm{~d}, 2 \mathrm{H}, \mathrm{Ar}, J 8.4$ $\mathrm{Hz}$ ), 6.93 (d, 2H, Ar, J 8.4 Hz), 7.13 (d, 2H, Ar, J $8.4 \mathrm{~Hz}$ ), 7.44 (d, 2H, Ar, J 8.4 Hz), 7.52 (d, 2H, Ar, J $8.4 \mathrm{~Hz}), 7.64$ $(\mathrm{d}, 2 \mathrm{H}, \mathrm{Ar}, J 8.4 \mathrm{~Hz}) ;{ }^{13} \mathrm{C}$ NMR $\left(75 \mathrm{MHz}, \mathrm{CDCl}_{3}\right) \delta 14.0$, 14.1, 22.6, 22.7, 25.9, 26.0, 29.0, 29.1, 29.2, 29.3, 29.4, $31.7,31.8,39.3,68.1,68.2,77.8,87.0,90.0,114.5,114.8$, $120.5,121.3,121.9,128.6,132.6,133.0,149.8,155.7$, 159.3, 161.1, 168.6; EI-MS: $m / z 609$ [M+], 496, 494, 480, 418, 380, 349, 321, 306, 305, 288, 258, 233, 218 (100), 205, 191, 129, 115 and 91.

\section{General procedure for synthesis of homologue series $7 \mathbf{a}-\mathrm{g}$}

The corresponding alcohol $2 \mathbf{a}$ or $2 \mathbf{c}\left(5.8 \times 10^{-4} \mathrm{~mol}\right)$ and the respective $p$ - $n$-alkoxybenzoic acid $\left(5.8 \times 10^{-4} \mathrm{~mol}\right)$ were suspended in dry THF $(5 \mathrm{~mL})$ and stirring for 15 min under argon atmosphere. Then DCC $\left(8.7 \times 10^{-4} \mathrm{~mol}\right)$ and DMAP $\left(7.6 \times 10^{-5} \mathrm{~mol}\right)$ were added. The reaction mixture was stirred for $24 \mathrm{~h}$ at room temperature. The white precipitate was filtered off and washed with THF. The solvent was removed and the crude product was recrystallized from ethanol (double recrystallization).

Representative data for [3-(4-heptyloxyphenyl)-4,5dihydroisoxazol-5-yl]methyl 4-decyloxybenzoate (7e)

Yield: $83.0 \mathrm{mg}, 60 \%$; white solid; $\mathrm{mp} 102.5{ }^{\circ} \mathrm{C}$; Anal Found: C, 74.15; H, 9.13; N, 2.54; calc. for $\mathrm{C}_{34} \mathrm{H}_{49} \mathrm{NO}_{5}$ : C, $74.01 ; \mathrm{H}, 8.95 ; \mathrm{N}, 2.54 \%$; IR $v_{\max } / \mathrm{cm}^{-1}: 2924,2854,1715$, 1606, 1510, 1466, 1377, 1249, 1169, 1127, 1014, 882, 834, 768, 722, 699, 666, 649; ${ }^{1} \mathrm{H}$ NMR (300 MHz, $\left.\mathrm{CDCl}_{3}\right) \delta$ $0.89\left(\mathrm{~m}, 6 \mathrm{H},\left(\mathrm{CH}_{3}\right)_{2}\right), 1.38\left(\mathrm{~m}, 22 \mathrm{H},\left(\mathrm{CH}_{2}\right)_{11}\right), 1.79(\mathrm{~m}, 4 \mathrm{H}$, $\left.\left(\mathrm{CH}_{2} \mathrm{CH}_{2} \mathrm{O}\right)_{2}\right), 3.22(\mathrm{dd}, J 16.5,6.9 \mathrm{~Hz}, 1 \mathrm{H}, \mathrm{N}=\mathrm{CC} \underline{\mathrm{HHCH}})$, 3.49 (dd, $J 16.5,10.8 \mathrm{~Hz}, 1 \mathrm{H}, \mathrm{N}=\mathrm{CCH} \underline{\mathrm{HCH}}), 3.98$ (t, $J 6.6$ $\left.\mathrm{Hz}, 4 \mathrm{H},\left(\mathrm{CH}_{2} \mathrm{O}\right)_{2}\right), 4.44\left(\mathrm{~m}, 2 \mathrm{H}, \mathrm{CHCH}_{2} \mathrm{OCO}\right), 5.06$ (m, $1 \mathrm{H}), 6.85(\mathrm{~d}, J 8.7 \mathrm{~Hz}, 2 \mathrm{H}, \mathrm{Ar}), 6.91$ (d, $J 8.4 \mathrm{~Hz}, 2 \mathrm{H}, \mathrm{Ar})$, $7.61(\mathrm{~d}, J 8.7 \mathrm{~Hz}, 2 \mathrm{H}, \mathrm{Ar}), 7.95(\mathrm{~d}, J 9.0 \mathrm{~Hz}, 2 \mathrm{H}, \mathrm{Ar}) ;{ }^{13} \mathrm{C}$ $\mathrm{NMR}\left(75 \mathrm{MHz}, \mathrm{CDCl}_{3}\right) \delta 14.0,14.1,22.5,22.6,25.9,28.9$, $29.0,29.1,29.2,29.3,29.5,31.7,31.8,37.6,65.2,68.0$,
68.1, 78.0, 114.0, 114.6, 121.5, 121.6, 128.2, 131.7, 155.8, 160.7, 163.1, 166.0; EI-MS: $m / z$ 436, 360, 325, 291, 290, 277, 274, 260, 235 (100), 190, 156, 116 and 91.

\section{General procedure of the series 8 a-d}

(i) Esterification reaction: alcohol 2a $(4.4 \mathrm{mmol})$ and $p$-bromobenzoic acid $(4.4 \mathrm{mmol})$ were suspended in dry THF $(30 \mathrm{~mL})$ and stirred for 15 min under argon atmosphere. Then DCC (6.6 mmol) and DMAP $(0.58 \mathrm{mmol})$ were added. The reaction mixture was stirred for $24 \mathrm{~h}$ at room temperature. The white precipitate was filtered off and washed with THF. The solvent from the filtrate was removed and the solid was recrystallized twice from ethanol to afford the corresponding esters as white crystals in 70-90\% of yield. All the compounds gave satisfactory analytical data. (ii) Sonogashira's coupling: A one-neck round-bottom flask equipped with septum stoppers was charged with the ester produced in step $(i)(0.8 \mathrm{mmol})$, the corresponding 1-alkoxy-4-ethynylbenzene (1.2 mmol) and $\mathrm{Et}_{3} \mathrm{~N}(20 \mathrm{~mL})$ under argon atmosphere. The suspension was stirred for $20 \mathrm{~min}$ and then $\mathrm{CuI}\left(1.2 \times 10^{-5} \mathrm{~mol}\right), \mathrm{PPh}_{3}$ $\left(4.0 \times 10^{-5} \mathrm{~mol}\right)$ and $\left[\mathrm{PdCl}_{2}\left(\mathrm{PPh}_{3}\right)_{2}\right]\left(0.8 \times 10^{-5} \mathrm{~mol}\right)$ were added. The mixture was heated under reflux for $48 \mathrm{~h}$. The solution was cooled to room temperature and the solid was filtered through a Celite ${ }^{\circledast}$ pad and washed with diethyl ether $(2 \times 100 \mathrm{~mL})$. The filtrate was then extracted with $\mathrm{H}_{2} \mathrm{O}$ $(4 \times 20 \mathrm{~mL})$ and the organic extracts were dried $\left(\mathrm{Na}_{2} \mathrm{SO}_{4}\right)$ and the solvent evaporated. The solid was recrystallized in ethanol affording the respective products.

Representative data for [3-(4-heptyloxyphenyl)-4,5dihydroisoxazol-5-yl]methyl 4-[(octyl oxyphenyl)ethynyl] benzoate $(8 \boldsymbol{b})$

Yield: $63 \mathrm{mg}, 40 \%$; orange solid; mp $138.4{ }^{\circ} \mathrm{C}$; Anal. Found: C, 76.96; H, 8.07; N, 2.14; calc. for $\mathrm{C}_{40} \mathrm{H}_{49} \mathrm{NO}_{5}$ : C, $77.01 ; \mathrm{H}, 7.92 ; \mathrm{N}, 2.25 \%$; IR $v_{\text {max }} / \mathrm{cm}^{-1}: 2924,2855,1723$, 1600, 1517, 1465, 1377, 1286, 1251, 1177, 1108, 1045, 890, 834, 765, 721, 695, 666; ${ }^{1} \mathrm{H}$ NMR (300 MHz, $\mathrm{CDCl}_{3}$ ) $\delta 0.89\left(\mathrm{~m}, 6 \mathrm{H},\left(\mathrm{CH}_{3}\right)_{2}\right), 1.38\left(\mathrm{~m}, 18 \mathrm{H},\left(\mathrm{CH}_{2}\right)_{9}\right), 1.79(\mathrm{~m}$, $\left.4 \mathrm{H},\left(\mathrm{C}_{2} \mathrm{CH}_{2} \mathrm{O}\right)_{2}\right), 3.24$ (dd, 1H, N=CCㅍHCH, $J$ 16.5, 6.6 $\mathrm{Hz}), 3.52(\mathrm{dd}, 1 \mathrm{H}, \mathrm{N}=\mathrm{CCH} \underline{\mathrm{HCH}}, J 16.5,10.5 \mathrm{~Hz}), 3.98$ $\left(\mathrm{m}, 4 \mathrm{H},\left(\mathrm{CH}_{2} \mathrm{O}\right)_{2}\right), 4.43(\mathrm{dd}, 1 \mathrm{H}, \mathrm{CHC} \underline{H} H O C O, J$ 12.0, 5.4 $\mathrm{Hz}$ ), 4.50 (dd, 1H, CHCHHOCO, J 12.0, $4.2 \mathrm{~Hz}$ ), 5.08 (m, $1 \mathrm{H}), 6.87(\mathrm{~d}, 2 \mathrm{H}, \mathrm{Ar}, J 9.0 \mathrm{~Hz}), 6.92(\mathrm{~d}, 2 \mathrm{H}, \mathrm{Ar}, J 8.7 \mathrm{~Hz})$, 7.45 (d, 2H, Ar, J 9.0 Hz), 7.51 (d, 2H, Ar, J 8.4 Hz), 7.62 (d, $2 \mathrm{H}, \mathrm{Ar}, J 9.0 \mathrm{~Hz}), 7.97$ (d, 2H, Ar, J $8.4 \mathrm{~Hz}$ ); ${ }^{13} \mathrm{C}$ NMR $\left(75 \mathrm{MHz}, \mathrm{CDCl}_{3}\right) \delta 14.0,22.5,22.6,25.8,25.9,28.9,29.0$, 29.1, 29.3, 31.6, 31.7, 37.5, 65.7, 68.0, 77.8, 87.3, 92.9, $114.3,114.5,114.6,121.3,128.1,128.3,128.6,129.6$, 131.2, 133.1, 155.8, 159.6, 160.7, 165.7; EI-MS: $m / z 624$ 
$\left([\mathrm{M}+\mathrm{H}]^{+}\right), 623\left[\mathrm{M}^{+}\right], 430,364,349,333,306,290,274$, 260, 234 (100), 230, 204, 190, 116 and 91.

\section{Conclusions}

In this work a molecular platform for liquid-crystalline materials based on 3-arylisoxazolyl-5-carboxylic acid and 5-(hydroxymethyl)-3-aryl-2-isoxazoline was described. In this context, a new series of liquid-crystalline 5a-c, 6a, 7a-g and 8a-d derived from isoxazolinic molecular platforms were synthesized and their mesomorphic behavior was investigated using POM and DSC techniques. The compounds belonging to series 5a-c showed an enantiotropic nematic phase while $\mathbf{6}$ was not mesogenic. The monotropic smectic $\mathrm{C}$ phase of the third series was observed in 7c-g. The first two 7a-b did not exhibit a smectic LC phase. The last series 8a-d displayed a monotropic nematic phase. A theoretical study was performed in order to understand the phase behavior and structural features of these compounds. The reported calculations further support the role of the insertion of a methylene unit between the isoxazoline ring and the carboxylate group disfavoring the molecular interaction in the liquid-crystalline state.

\section{Acknowledgments}

This work was supported by Conselho Nacional de Desenvolvimento Científico e Tecnológico (project MCT/ CNPq No. 555785/2006-8 and MCT/CNPq Universal No. 471194/2008-5), PROCAD-CAPES, INCT-CMN/CNPq and Coordenação de Aperfeiçoamento de Pessoal de Nível Superior (CAPES) for fellowship.

\section{Supplementary Information}

Copies of ${ }^{1} \mathrm{H} N M R,{ }^{13} \mathrm{C}$ NMR spectrum and ESI-MS are available free of charge at http://jbcs.sbq.org.br, as PDF file.

\section{References}

1. Carmella, P.; Grünanger, P.; 1,3-Dipolar Cycloaddition Chemistry; Padwa, A., ed.; Wiley: New York, 1984; vol. 1, pp. 291-392; Torsell, K. B. G.; Nitrile Oxides, Nitrones and Nitronates; VCH: Weinheim, 1988.

2. Kozikowski, A. P.; Acc. Chem. Res. 1984, 17, 410; Jager, V.; Muller, I.; Tetrahedron 1985, 41, 3519.

3. Curran, D. P.; Zhang, J.; J. Chem. Soc. Perkin Trans. I 1991, 2613.

4. Kenar, J. A.; J. Am. Oil Chem. Soc. 2002, 79, 351.

5. Kovganko, V. N.; Kovganko, N. N.; Russ. J. Org. Chem. 2006, 42, 696; Ritter, O. M. S.; Giacomelli, F. C.; Passo, J. A.; Silveira,
N. P.; Merlo, A. A.; Polym. Bull. 2006, 56, 549; Kauhanka, U. M.; Kauhanka, M. M.; Liq. Cryst. 2006, 33, 121; Bezborodov, V.; Kauhanka, N.; Lapanik, V.; Mol. Cryst. Liq. Cryst. 2004, 411, 1145; Merlo, A. A.; Gallardo, H.; Taylor, T. R.; Quim. Nova 2001, 24, 354.

6. Tavares, A.; Schneider, P. H.; Merlo, A. A.; Eur. J. Org. Chem. 2009, 889; Passo, J. A.; Vilela, G. D.; Schneider, P. H.; Ritter, O. M. S.; Merlo, A. A.; Liq. Cryst. 2008, 35, 833; Gallardo, H.; Conte, G.; Bryk, F.; Lourenço, M. C. S.; Costa, M. S.; Ferreira, V. F.; J. Braz. Chem. Soc. 2007, 18, 1285.

7. Gimeno, N.; Ros, M. B.; De la Fuente, M. R.; Serrano, J. L.; Chem. Mater. 2008, 20, 1262; Naoum, M. M.; Saad, G. R.; Nessim, R. I.; Abdel Aziz, T. A.; Seliger, H.; Liq. Cryst. 1997, 23, 789 .

8. Vasconcelos, U. B.; Dalmolin, E.; Merlo, A. A.; Org. Lett. 2005, 7, 1027; Vasconcelos, U. B.; Merlo, A. A.; Synthesis 2006, 7, 1141; Vasconcelos, U. B.; Vilela, G. D.; Schrader, A.; Borges, A. C. A.; Merlo, A. A.; Tetrahedron 2008, 64, 4619; Sonogashira, K.; Tohda, Y.; Hagihara, N.; Tetrahedron Lett. 1975, 16, 4467; Chinchilla, R.; Nájera, C.; Chem. Rev. 2007, 107, 874; Cristiano, R.; Santos, D. M. P. O.; Conte, G.; Gallardo, H.; Liq. Cryst. 2006, 33, 997; Melissaris, A. P.; Litt, M. H.; Macromolecules 1994, $27,883$.

9. Gray, G. W.; Goodby, J. W. G.; Smectic Liquid Crystals. Textures and Structures; Leonard Hill: London, 1984.

10. Frisch, M. J.; Trucks, G. W.; Schlegel, H. B.; Scuseria, G. E.; Robb, M. A.; Cheeseman, J. R.; Zakrzewski, V. G.; Montgomery J. A.; Stratmann, Jr., R. E.; Burant, J. C.; Dapprich, S.; Millam, J. M.; Daniels, A. D.; Kudin, K. N.; Strain, M. C.; Farkas, O.; Tomasi, J.; Barone, V.; Cossi, M.; Cammi, R.; Mennucci, B.; Pomelli, C.; Adamo, C.; Clifford, S.; Ochterski, J.; Petersson, G. A.; Ayala, P. Y.; Cui, Q.; Morokuma, K.; Malick, D. K.; Rabuck, A. D.; Raghavachari, K.; Foresman, J. B.; Cioslowski, J.; Ortiz, J. V.; Stefanov, B. B.; Liu, G.; Liashenko, A.; Piskorz, P.; Komaromi, I.; Gomperts, R.; Martin, R. L.; Fox, D. J.; Keith, T.; Al-Laham, M. A.; Peng, C. Y.; Nanayakkara, A.; Gonzalez, C.; Challacombe, M.; Gill, P. M. W.; Johnson, B.; Chen, W.; Wong, M. W.; Andres, J. L.; Gonzalez, C.; Head-Gordon, M.; Replogle, E. S.; Pople, J. A.; Gaussian 98, Revision A.5. Gaussian, Inc.: Pittsburgh, PA., 1998; Becke, A. D.; J. Chem. Phys. 1993, 98, 5648; Lee, C.; Yang, W.; Parr, R. G.; Phys. Rev. $B$ 1988, 37, 785.

11. Dingemans, T. J.; Samulski, E. T.; Liq. Cryst. 2000, 27, 131; Cai, R.; Samulsky, E. T.; Liq. Cryst. 1991, 9, 617.

12. Vieira, A.; Bryk, F.; Conte, G.; Bortoluzzi, A.; Gallardo, H.; Tetrahedron Lett. 2009, 50, 905; Gallardo H.; Cristiano, R.; Ely, F.; Vieira, A.; Liq. Cryst. 2006, 33, 381.

13. King, A. O.; Negishi, E.; J. Org. Chem. 1978, 43, 358.

Received: March 31, 2009

Web Release Date: September 25, 2009 


\title{
3-Arylisoxazolyl-5-Carboxylic Acid and 5-(Hydroxymethyl)-3-Aryl-2-Isoxazoline as Molecular Platforms for Liquid-crystalline Materials
}

\author{
Aline Tavares, ${ }^{a}$ Paolo R. Livotto, ${ }^{a}$ Paulo F. B. Gonçalves ${ }^{b}$ and Aloir A. Merlo ${ }^{*, a}$
}

${ }^{a}$ Instituto de Química, Universidade Federal do Rio Grande do Sul, 91501-970 Porto Alegre-RS, Brazil

${ }^{b}$ Centro Universitário La Salle, 92010-000 Canoas-RS, Brazil

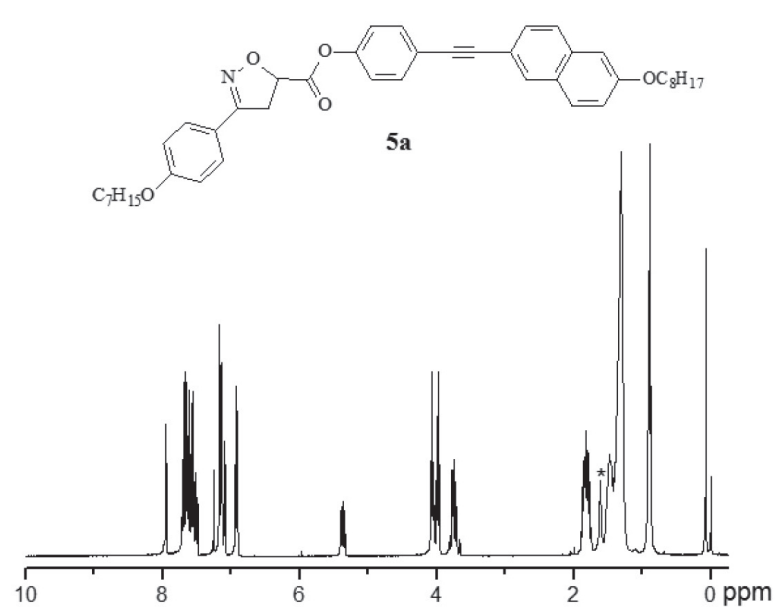

Figure S1. ${ }^{1} \mathrm{H}$ NMR spectrum of compound $\mathbf{5 a}\left(\mathrm{CDCl}_{3}, 300 \mathrm{MHz}\right)$. *Solvent impurity.

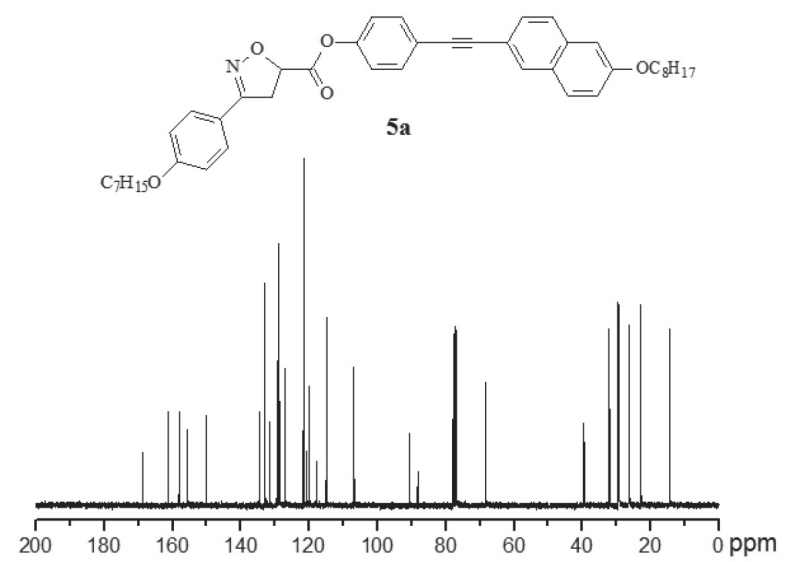

Figure S2. ${ }^{13} \mathrm{C}$ NMR spectrum of compound $\mathbf{5 a}\left(\mathrm{CDCl}_{3}, 75 \mathrm{MHz}\right)$.

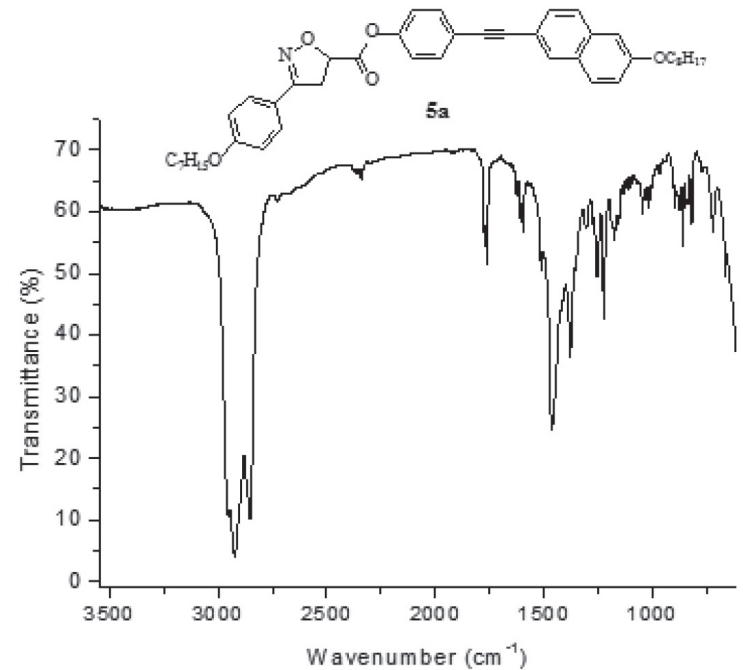

Figure S3. FT-IR spectrum of compound 5a (nujol).

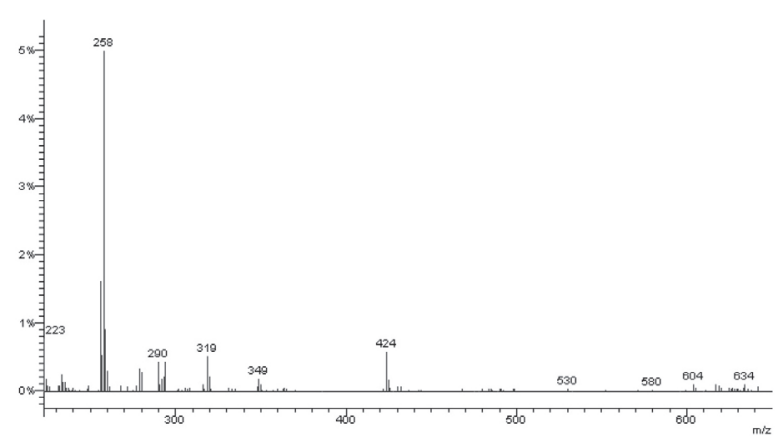

Figure S4. Mass spectra (EI-MS) of compound $\mathbf{5 a}$. 


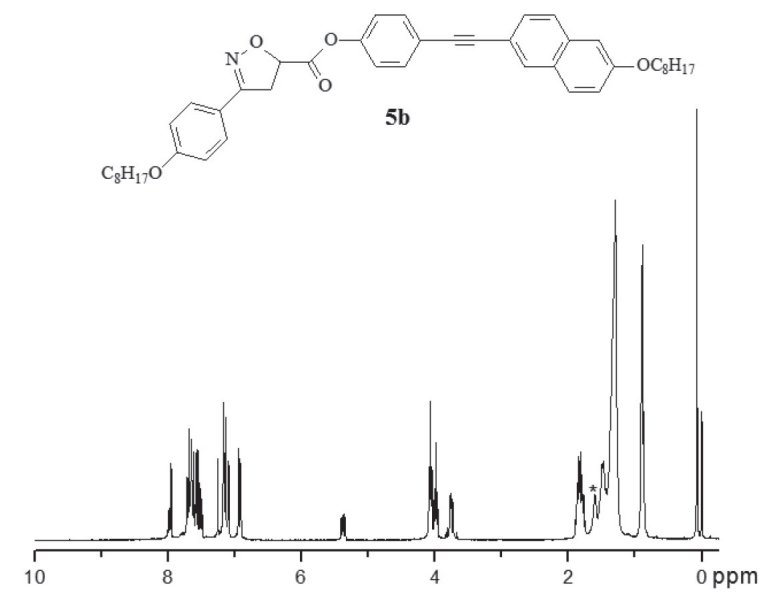

Figure S5. ${ }^{1} \mathrm{H}$ NMR spectrum of compound $\mathbf{5 b}\left(\mathrm{CDCl}_{3}, 300 \mathrm{MHz}\right)$. *Solvent impurity.

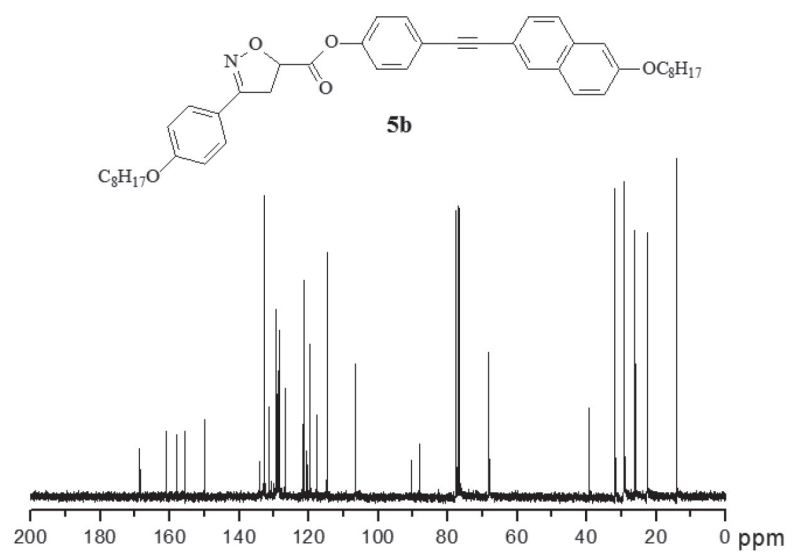

Figure S6. ${ }^{13} \mathrm{C}$ NMR spectrum of compound $\mathbf{5 b}\left(\mathrm{CDCl}_{3}, 75 \mathrm{MHz}\right)$.

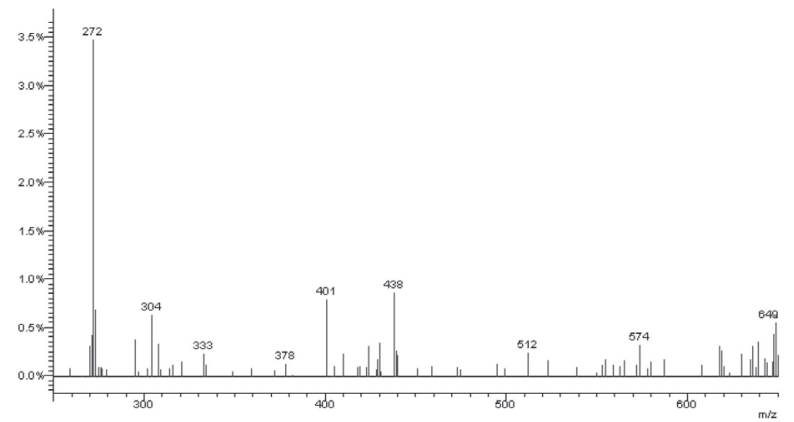

Figure S7. Mass spectra (EI-MS) of compound $\mathbf{5 b}$.

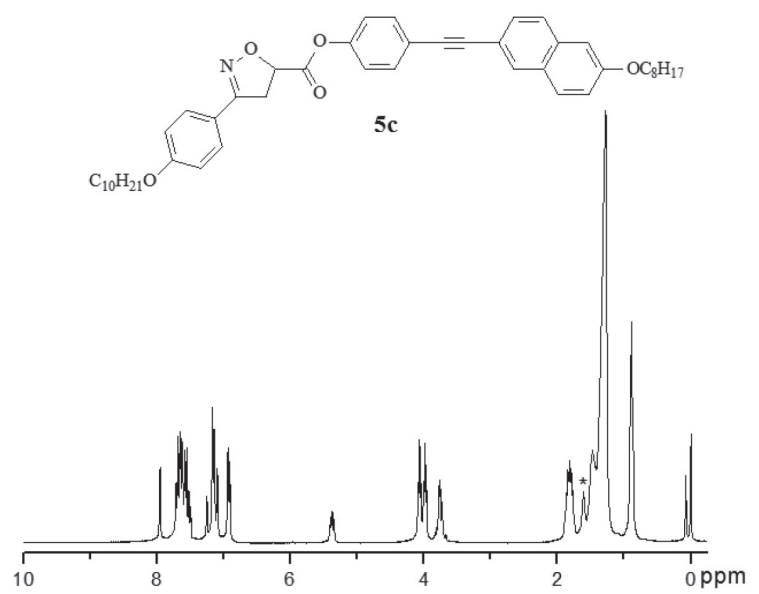

Figure S8. ${ }^{1} \mathrm{H}$ NMR spectrum of compound $\mathbf{5 c}\left(\mathrm{CDCl}_{3}, 300 \mathrm{MHz}\right)$. *Solvent impurity.

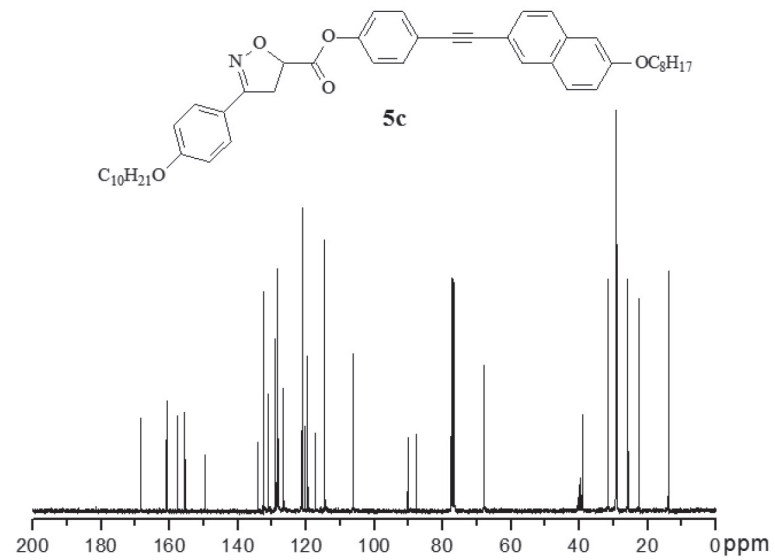

Figure S9. ${ }^{13} \mathrm{C}$ NMR spectrum of compound $\mathbf{5 c}\left(\mathrm{CDCl}_{3} / \mathrm{DMSO}_{6}, \mathrm{~d}_{6}, 75\right.$ $\mathrm{MHz}$ ).

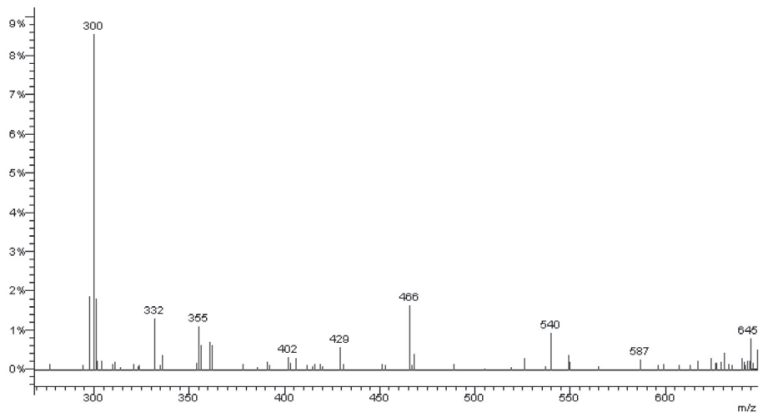

Figure S10. Mass spectra (EI-MS) of compound 5c 


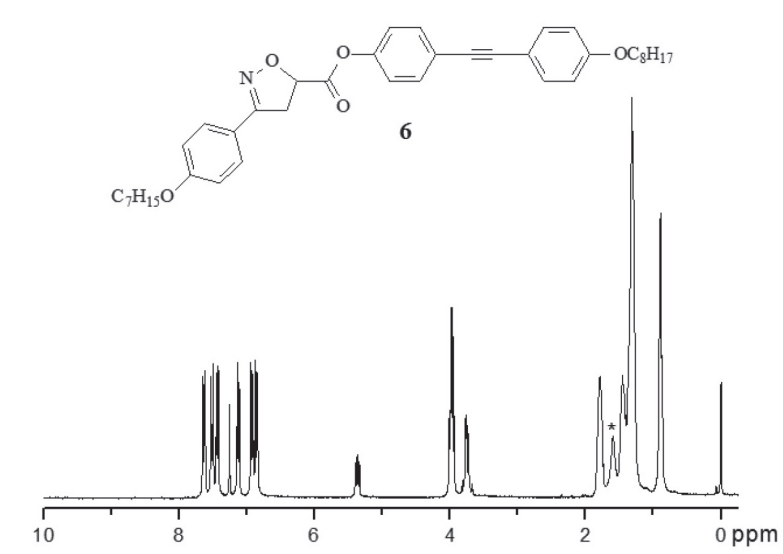

Figure S11. ${ }^{1} \mathrm{H}$ NMR spectrum of compound $6\left(\mathrm{CDCl}_{3}, 300 \mathrm{MHz}\right)$. *Solvent impurity.

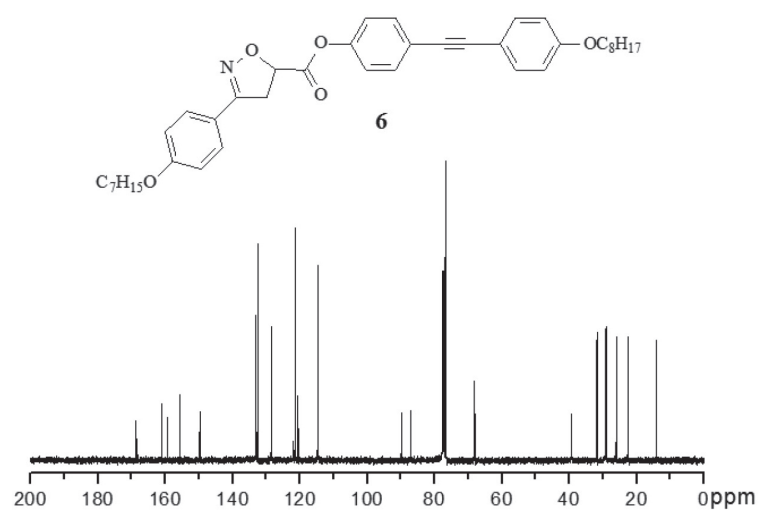

Figure S12. ${ }^{13} \mathrm{C}$ NMR spectrum of compound $6\left(\mathrm{CDCl}_{3}, 75 \mathrm{MHz}\right)$.

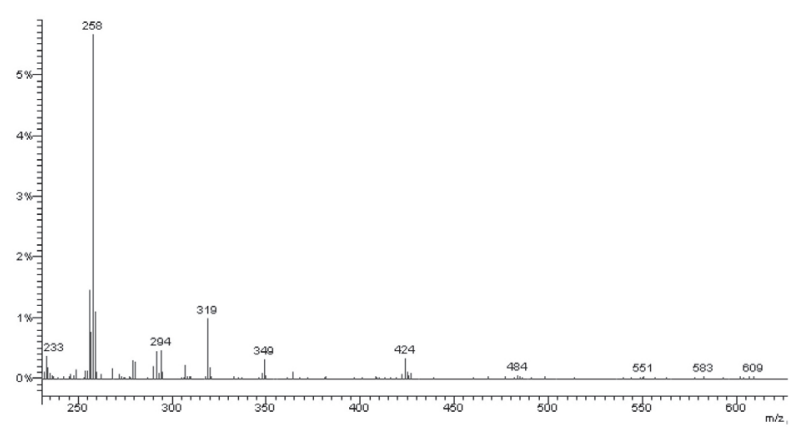

Figure S13. Mass spectra (EI-MS) of compound 6.

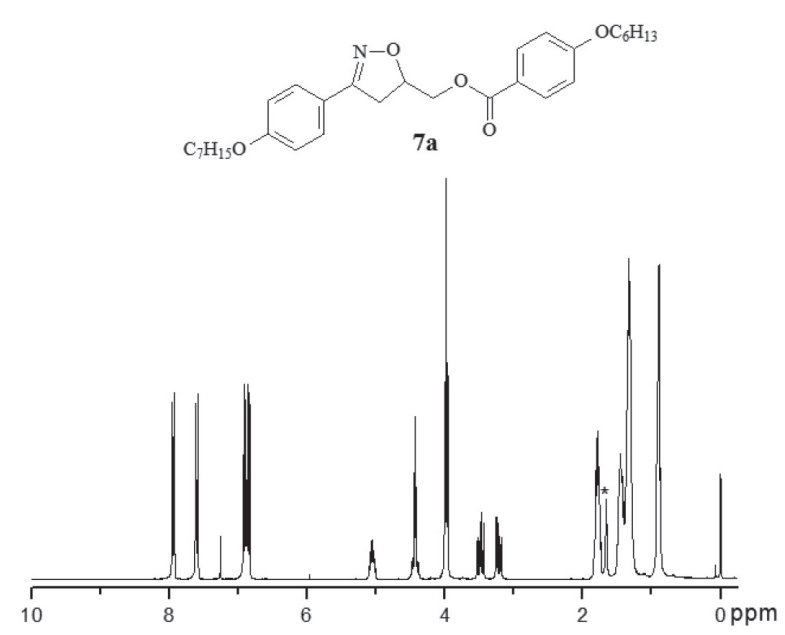

Figure S14. ${ }^{1} \mathrm{H}$ NMR spectrum of compound $7 \mathbf{a}\left(\mathrm{CDCl}_{3}, 300 \mathrm{MHz}\right)$. *Solvent impurity
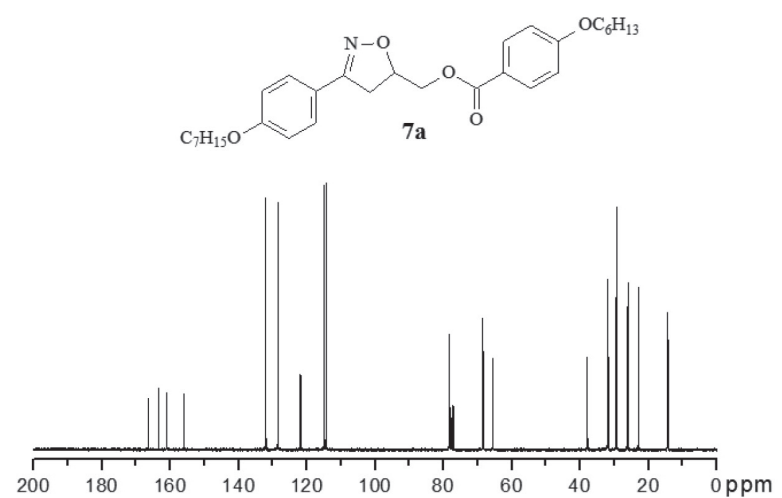

Figure S15. ${ }^{13} \mathrm{C}$ NMR spectrum of compound $7 \mathbf{a}\left(\mathrm{CDCl}_{3}, 75 \mathrm{MHz}\right)$.

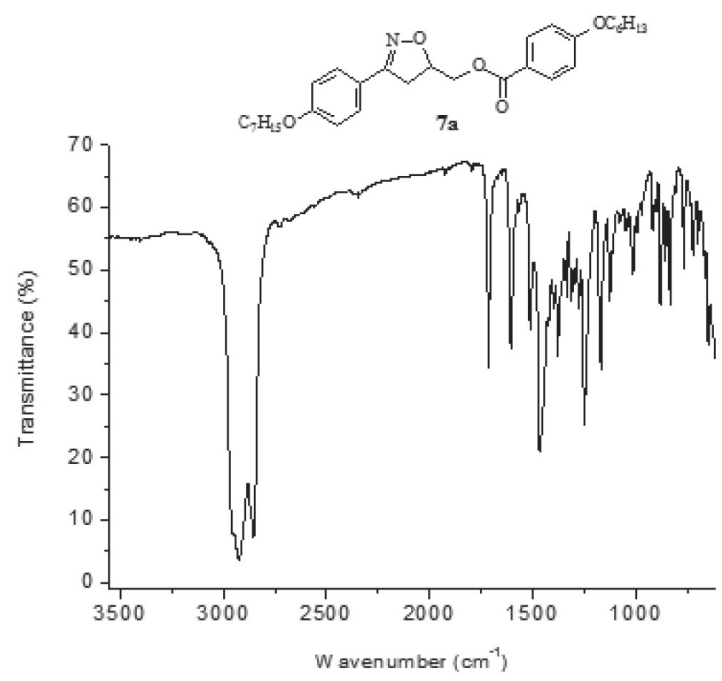

Figure S16. FT-IR spectrum of compound 7a (nujol). 


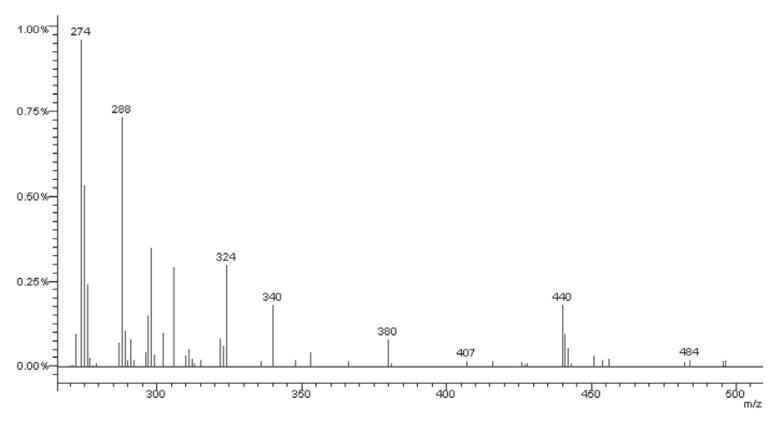

Figure S17. Mass spectra (EI-MS) of compound 7a.

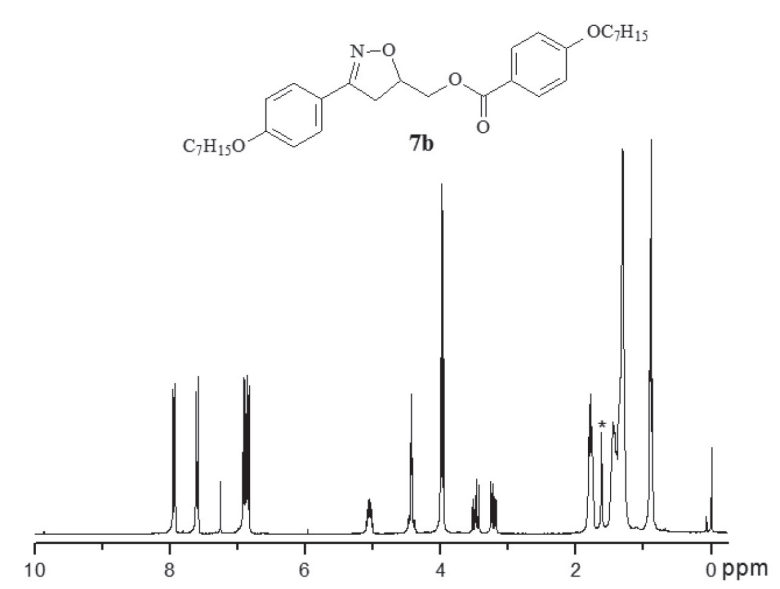

Figure S18. ${ }^{1} \mathrm{H}$ NMR spectrum of compound $\mathbf{7 b}\left(\mathrm{CDCl}_{3}, 300 \mathrm{MHz}\right)$. *Solvent impurity.

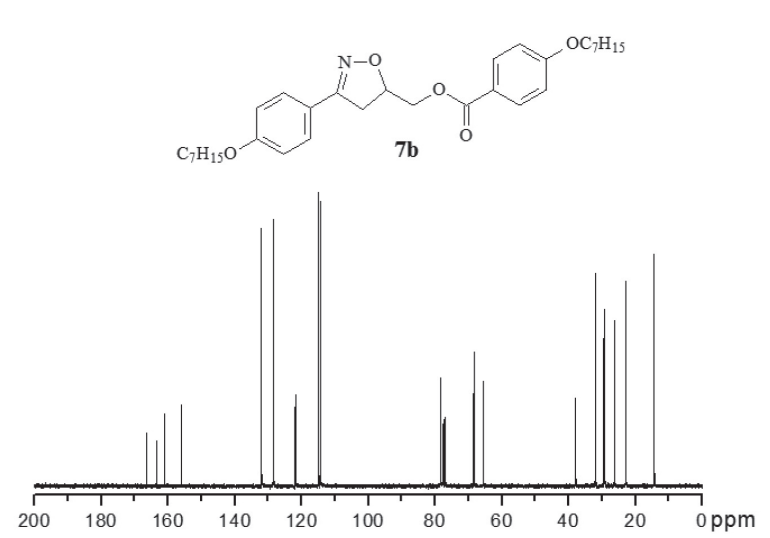

Figure S19. ${ }^{13} \mathrm{C}$ NMR spectrum of compound $7 \mathbf{b}\left(\mathrm{CDCl}_{3}, 75 \mathrm{MHz}\right)$.

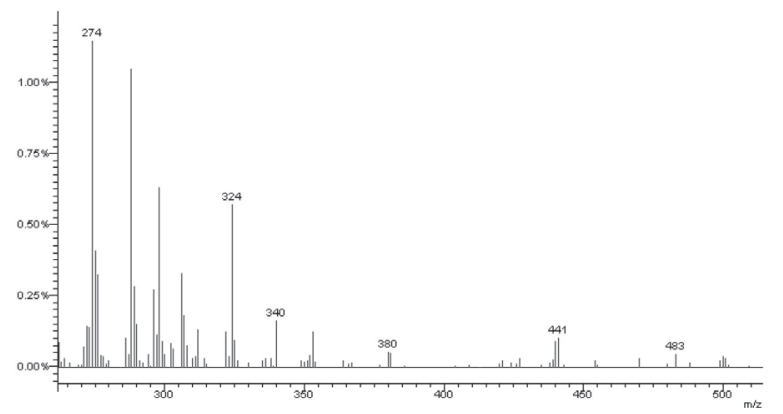

Figure S20. Mass spectra (EI-MS) of compound 7b.

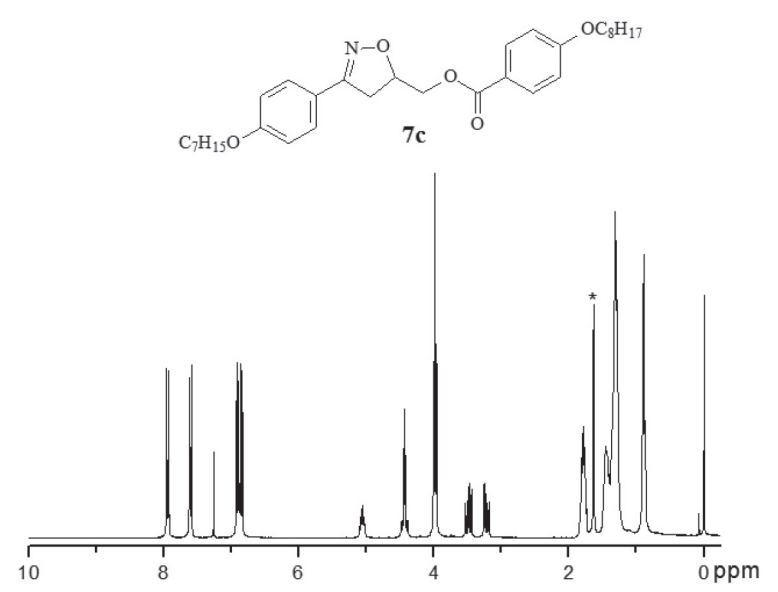

Figure S21. ${ }^{1} \mathrm{H}$ NMR spectrum of compound $7 \mathbf{c}\left(\mathrm{CDCl}_{3}, 300 \mathrm{MHz}\right)$. *Solvent impurity.

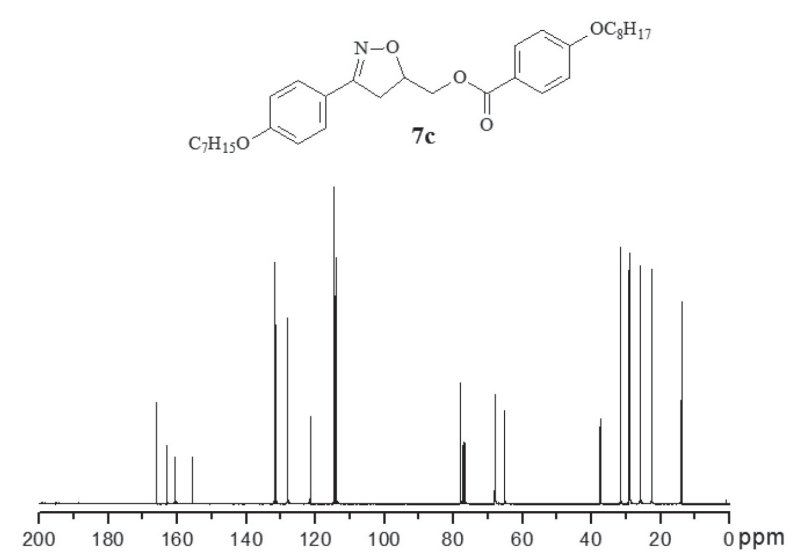

Figure S22. ${ }^{13} \mathrm{C}$ NMR spectrum of compound $7 \mathbf{c}\left(\mathrm{CDCl}_{3}, 75 \mathrm{MHz}\right)$. 


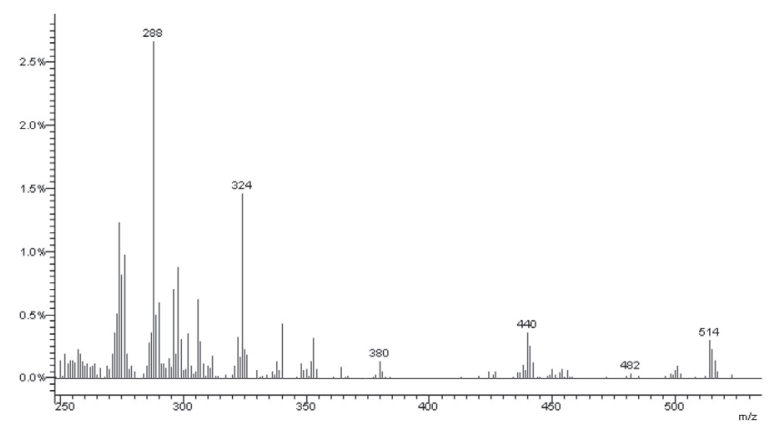

Figure S23. Mass spectra (EI-MS) of compound 7c.

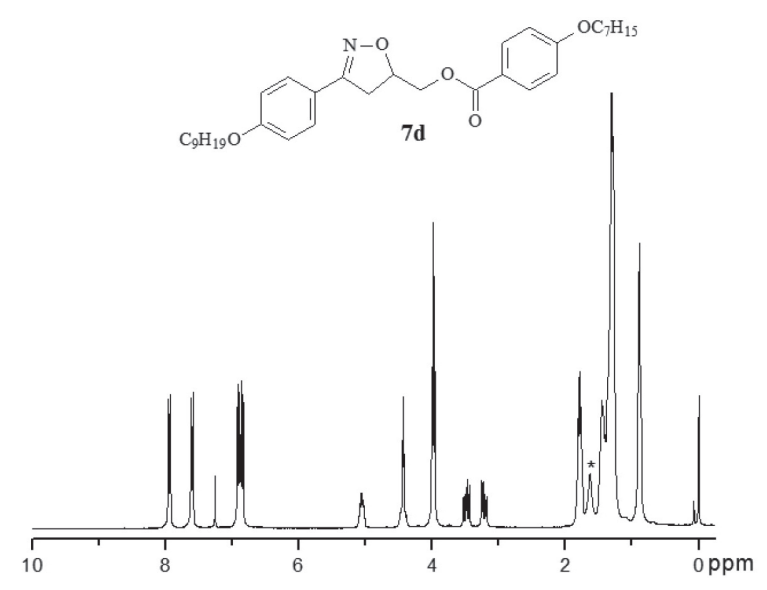

Figure S24. ${ }^{1} \mathrm{H}$ NMR spectrum of compound $\mathbf{7 d}\left(\mathrm{CDCl}_{3}, 300 \mathrm{MHz}\right)$. *Solvent impurity.

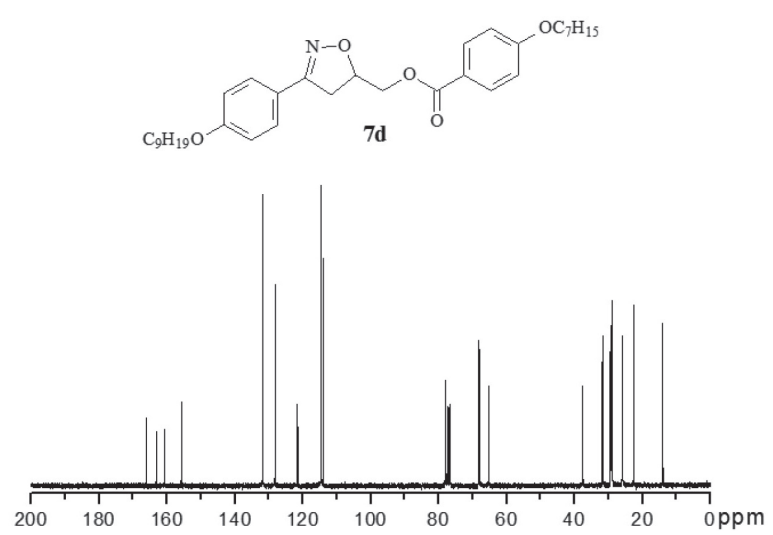

Figure S25. ${ }^{13} \mathrm{C}$ NMR spectrum of compound $7 \mathbf{d}\left(\mathrm{CDCl}_{3}, 75 \mathrm{MHz}\right)$.

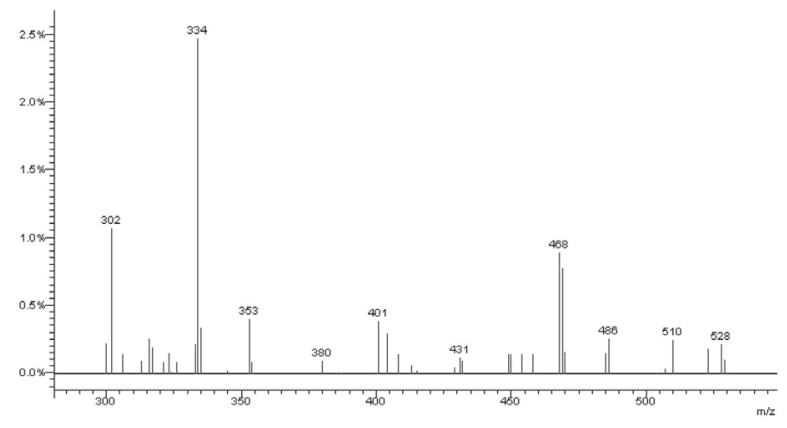

Figure S26. Mass spectra (EI-MS) of compound 7d.

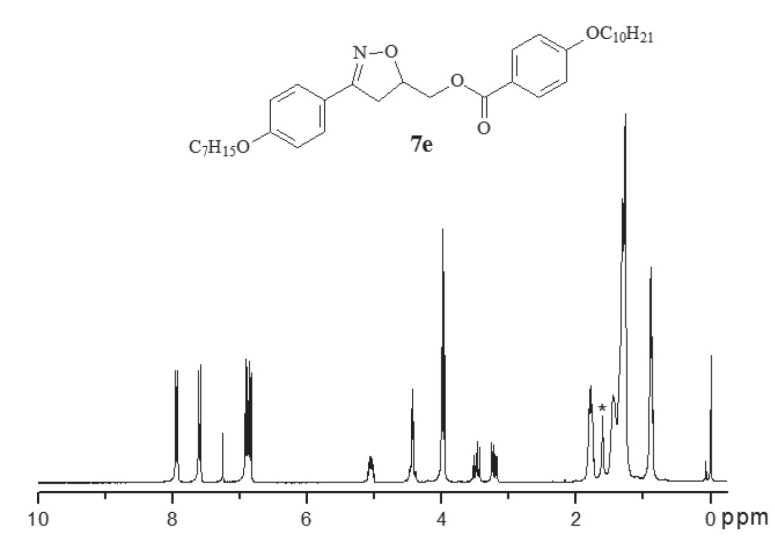

Figure S27. ${ }^{1} \mathrm{H}$ NMR spectrum of compound $7 \mathbf{e}\left(\mathrm{CDCl}_{3}, 300 \mathrm{MHz}\right)$. *Solvent impurity.

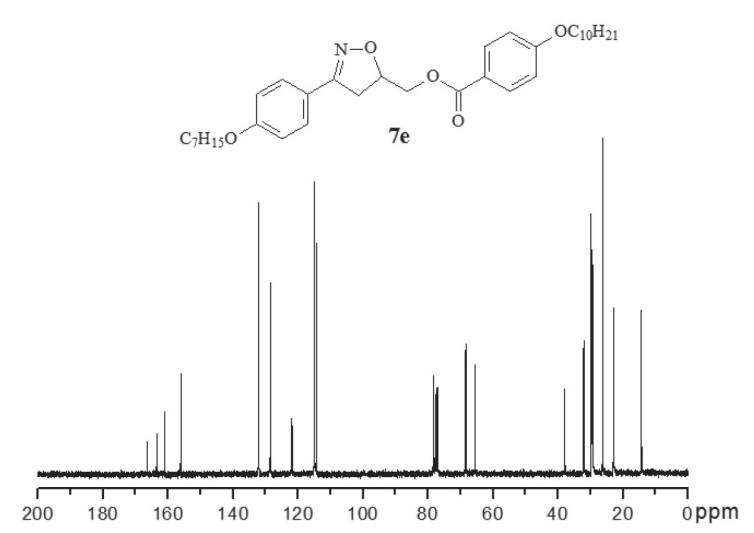

Figure S28. ${ }^{13} \mathrm{C}$ NMR spectrum of compound $7 \mathbf{e}\left(\mathrm{CDCl}_{3}, 75 \mathrm{MHz}\right)$. 


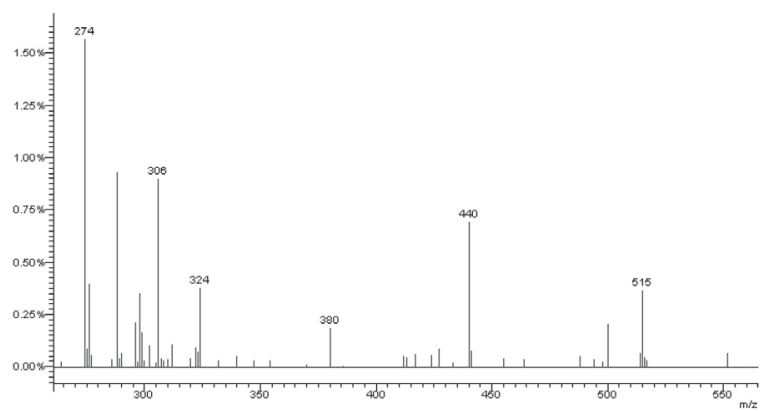

Figure S29. Mass spectra (EI-MS) of compound 7e.

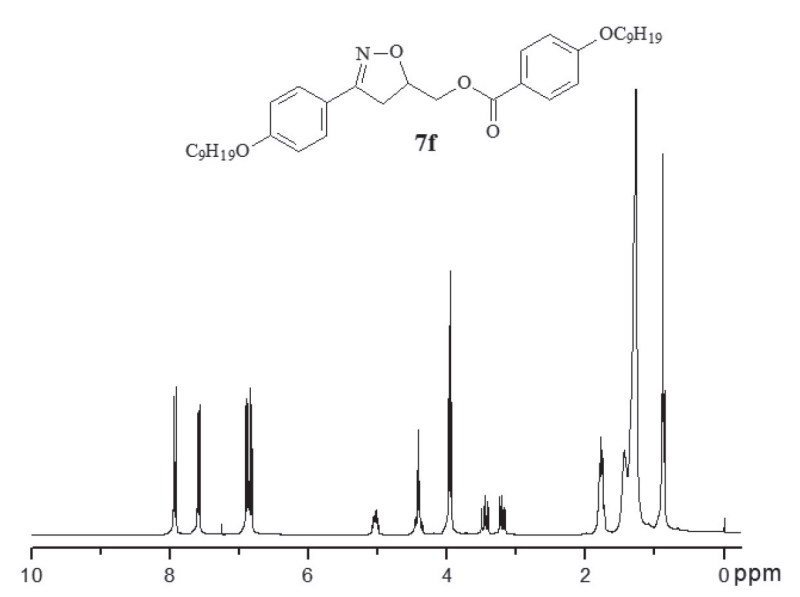

Figure S30. ${ }^{1} \mathrm{H}$ NMR spectrum of compound $7 \mathbf{f}\left(\mathrm{CDCl}_{3}, 300 \mathrm{MHz}\right)$.

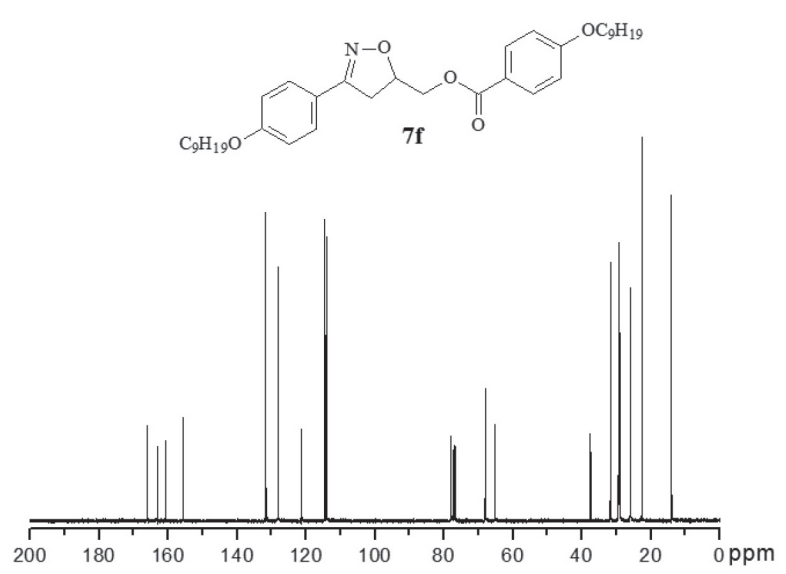

Figure S31. ${ }^{13} \mathrm{C}$ NMR spectrum of compound $7 \mathbf{f}\left(\mathrm{CDCl}_{3}, 75 \mathrm{MHz}\right)$.

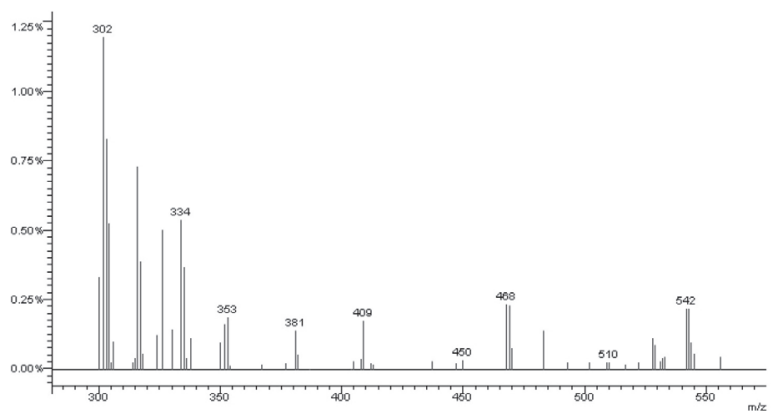

Figure S32. Mass spectra (EI-MS) of compound 7f.

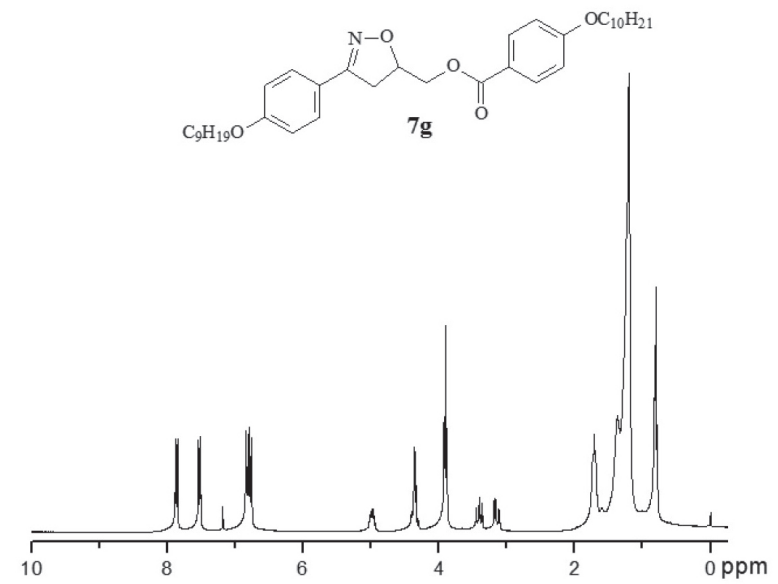

Figure S33. ${ }^{1} \mathrm{H}$ NMR spectrum of compound $7 \mathbf{g}\left(\mathrm{CDCl}_{3}, 300 \mathrm{MHz}\right)$.

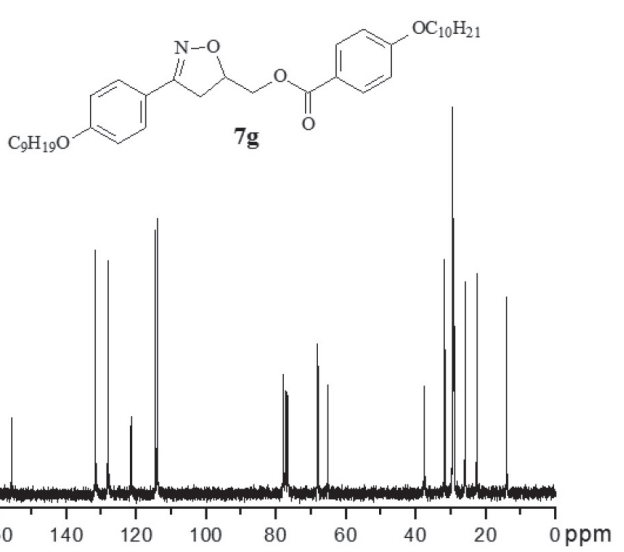

Figure S34. ${ }^{13} \mathrm{C}$ NMR spectrum of compound $7 \mathbf{g}\left(\mathrm{CDCl}_{3}, 75 \mathrm{MHz}\right)$. 


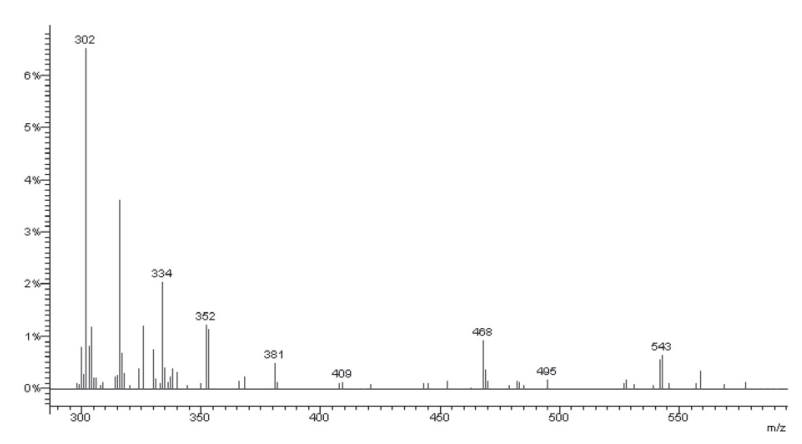

Figure S35. Mass spectra (EI-MS) of compound 7g.

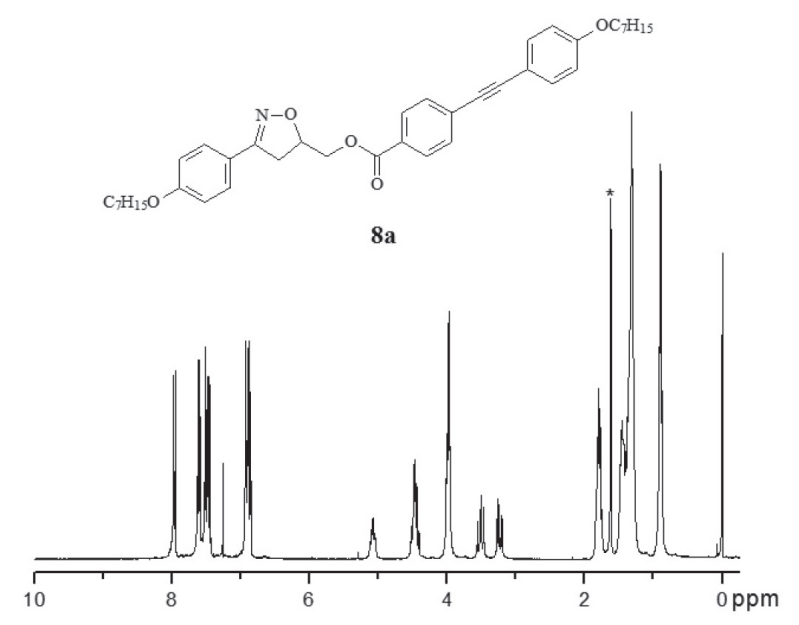

Figure S36. ${ }^{1} \mathrm{H}$ NMR spectrum of compound 8a $\left(\mathrm{CDCl}_{3}, 300 \mathrm{MHz}\right)$. *Solvent impurity.

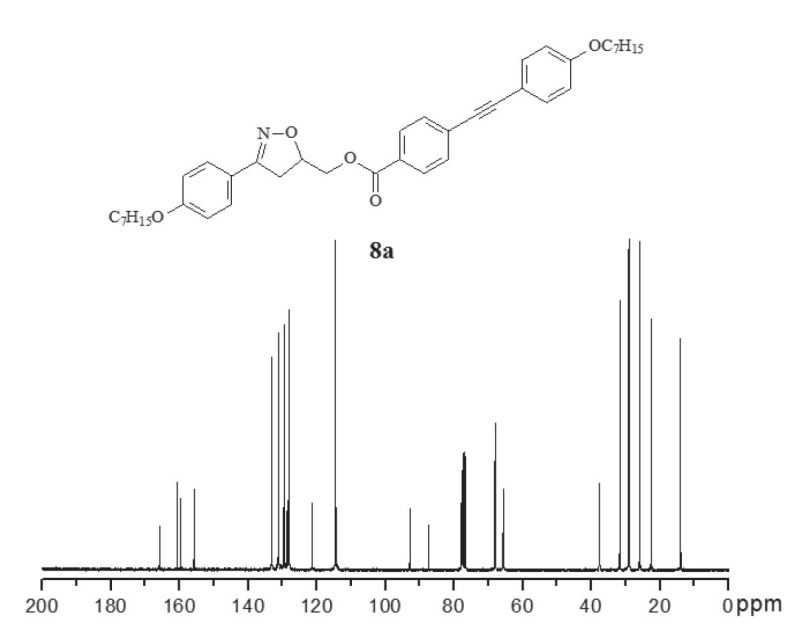

Figure S37. ${ }^{13} \mathrm{C}$ NMR spectrum of compound $8 \mathbf{a}\left(\mathrm{CDCl}_{3}, 75 \mathrm{MHz}\right)$.

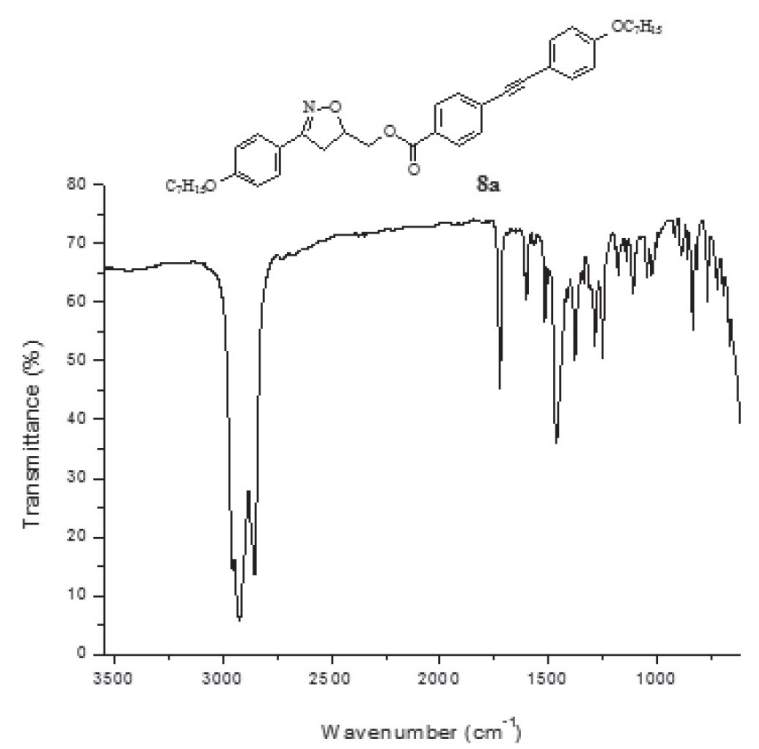

Figure S38. FT-IR spectrum of compound 8a (nujol).

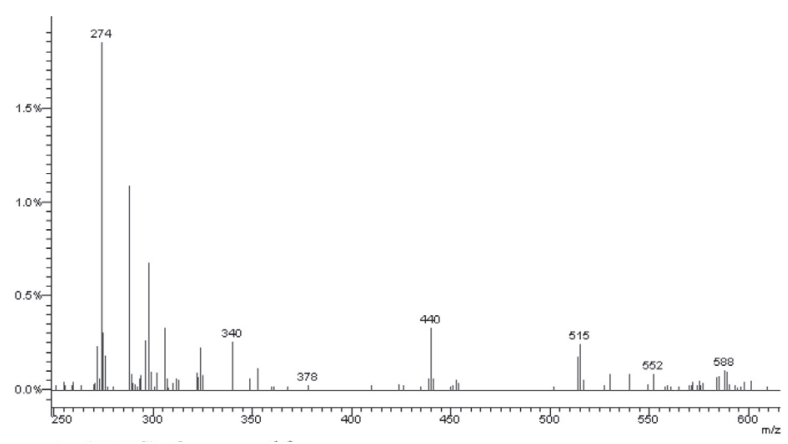

Figure S39. Mass spectra (EI-MS) of compound 8a.

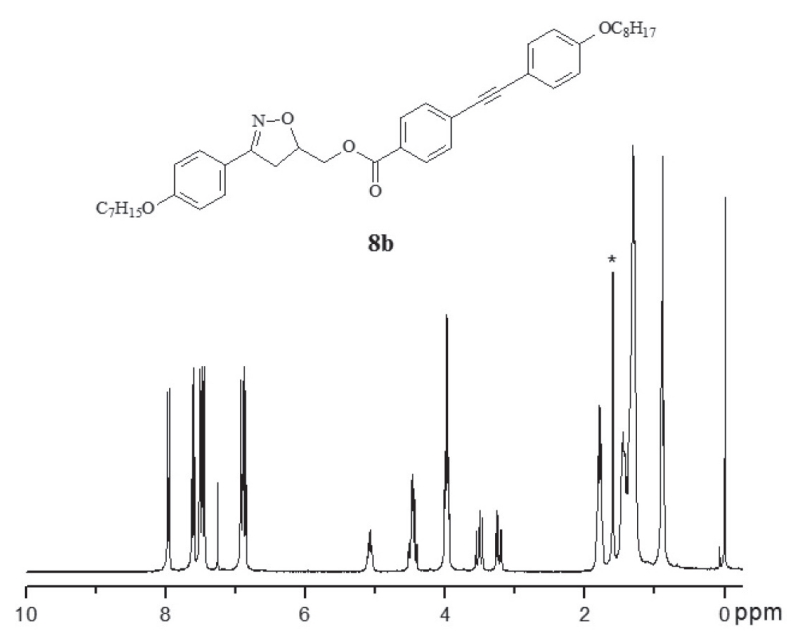

Figure S40. ${ }^{1} \mathrm{H}$ NMR spectrum of compound $\mathbf{8 b}\left(\mathrm{CDCl}_{3}, 300 \mathrm{MHz}\right)$. *Solvent impurity. 


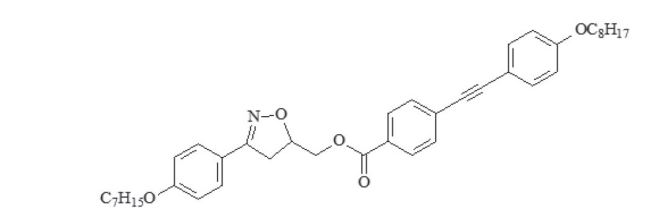

8b

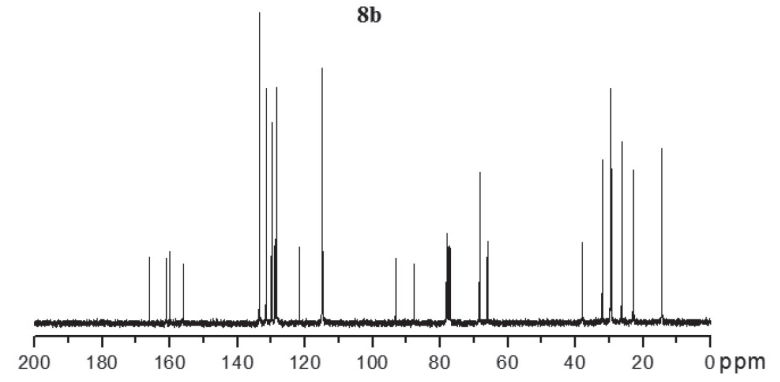

Figure S41. ${ }^{13} \mathrm{C}$ NMR spectrum of compound $\mathbf{8 b}\left(\mathrm{CDCl}_{3}, 75 \mathrm{MHz}\right)$.

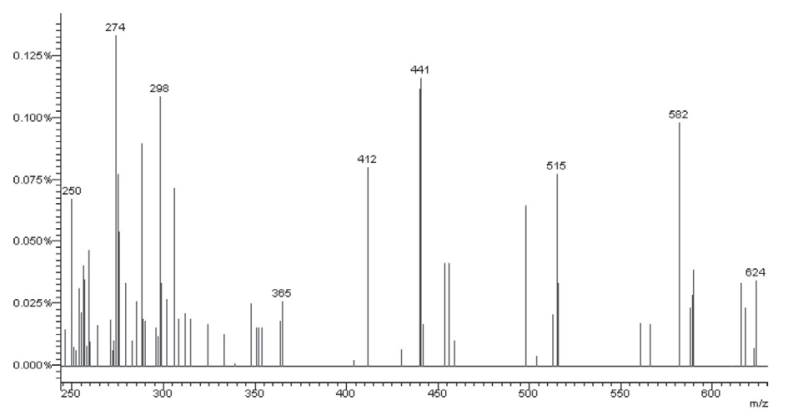

Figure S42. Mass spectra (EI-MS) of compound $\mathbf{8 b}$.

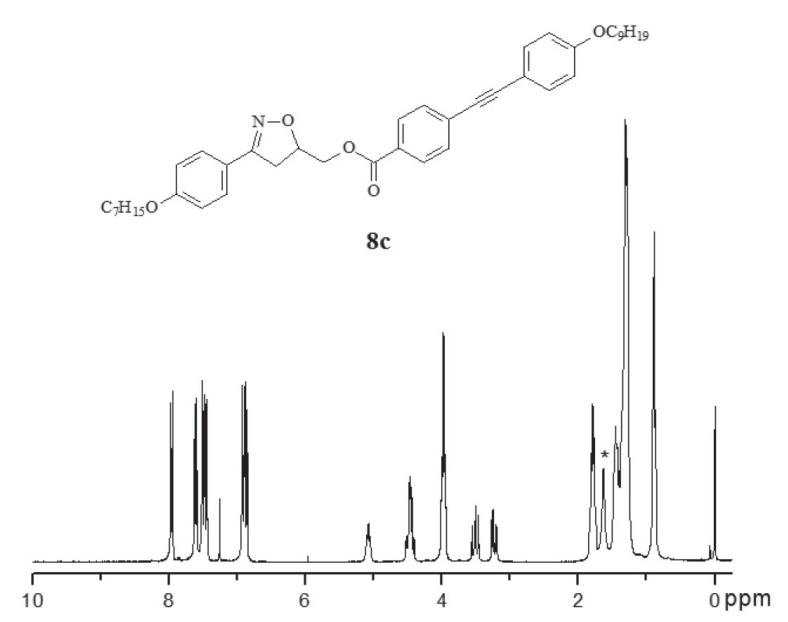

Figure S43. ${ }^{1} \mathrm{H}$ NMR spectrum of compound $\mathbf{8 c}\left(\mathrm{CDCl}_{3}, 300 \mathrm{MHz}\right)$. *Solvent impurity.

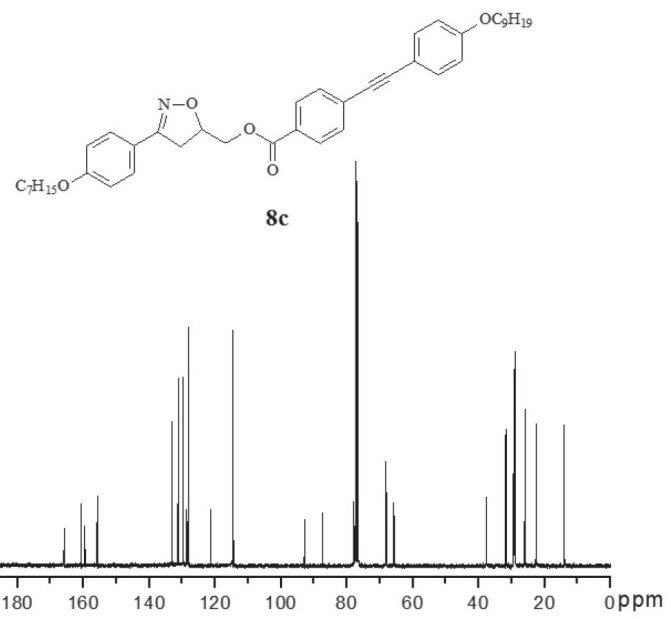

Figure S44. ${ }^{13} \mathrm{C}$ NMR spectrum of compound $8 \mathbf{c}\left(\mathrm{CDCl}_{3}, 75 \mathrm{MHz}\right)$.

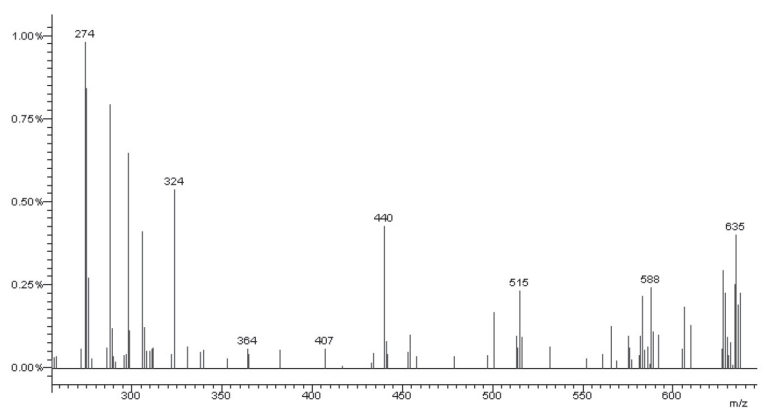

Figure S45. Mass spectra (EI-MS) of compound 8c.

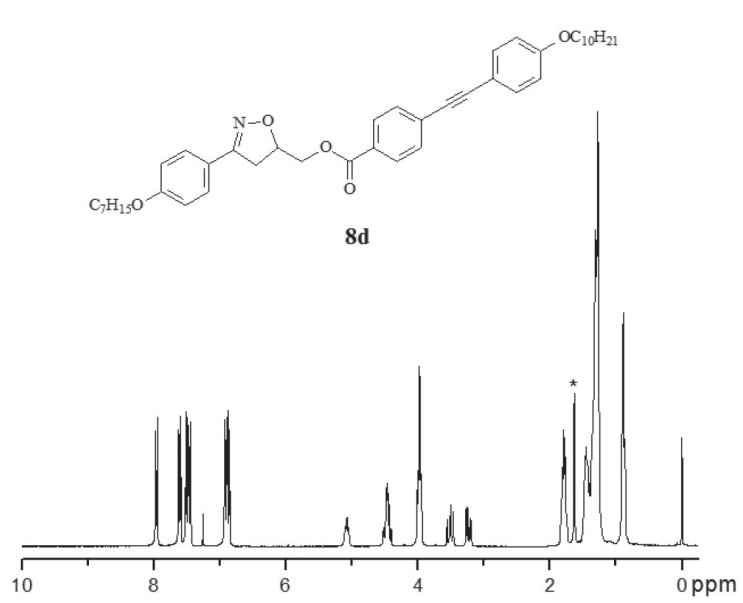

Figure S46. ${ }^{1} \mathrm{H}$ NMR spectrum of compound $\mathbf{8 d}\left(\mathrm{CDCl}_{3}, 300 \mathrm{MHz}\right)$. *Solvent impurity. 


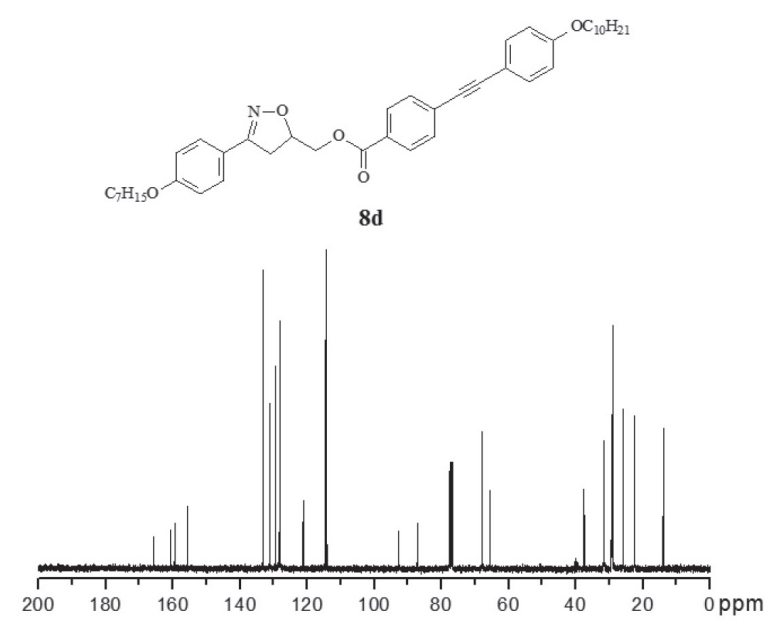

Figure S47. ${ }^{13} \mathrm{C}$ NMR spectrum of compound $8 d\left(\mathrm{CDCl}_{3} / \mathrm{DMSO}-\mathrm{d}_{6}\right.$, $75 \mathrm{MHz}$ ).

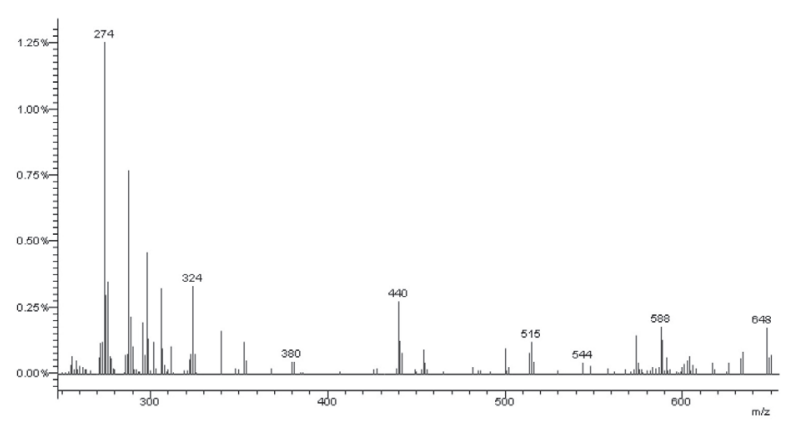

Figure S48. Mass spectra (EI-MS) of compound 8d. 